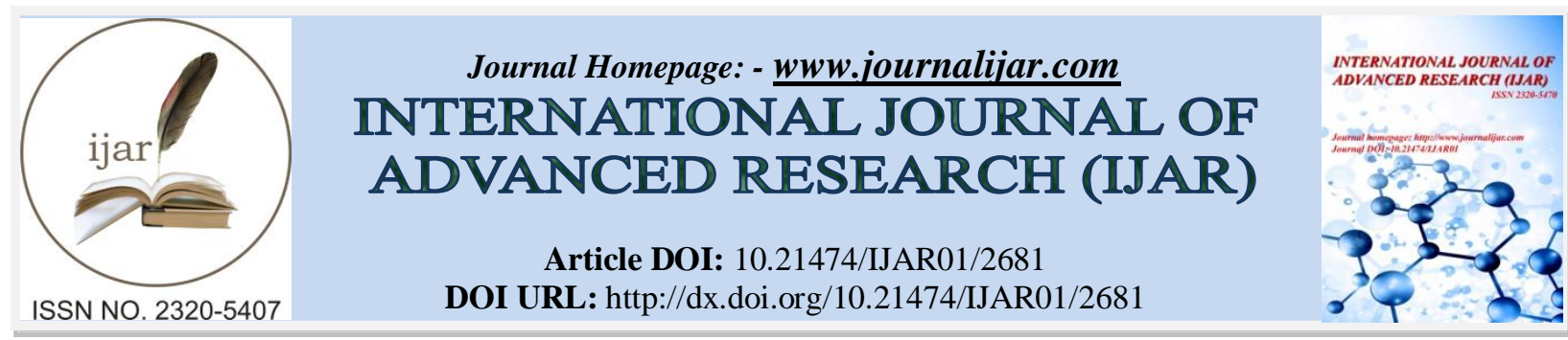

RESEARCH ARTICLE

\title{
METAL-BASED BIOLOGICALLY ACTIVE AGENTS: SYNTHESIS, CHARACTERIZATION, ANTIMICROBIAL AND BIOCHEMICAL STUDIES OF MIXED LIGAND COMPLEXES
}

G. Ayisha Bibin Rani.

Department of Chemistry, Nanjil Catholic College of Arts and Science, Kaliyakkavilai- 629180, Tamilnadu, India.

\section{Manuscript Info}

\section{Manuscript History}

Received: 31 October 2016

Final Accepted: 01 December 2016

Published: December 2016

Key words:-

4-aminoantipyrine, mixed ligand complex, disc diffusion, DNA binding, SOD

\section{Abstract}

Mixed ligand complexes of metals (Fe(III), $\mathrm{Co}(\mathrm{II}), \mathrm{Cu}(\mathrm{II}), \mathrm{Ni}(\mathrm{II})$ and $\mathrm{Zn}(\mathrm{II})$ ) with the Schiff bases of $\mathrm{L}^{1}$ and $\mathrm{HL}^{2}$ ( $\mathrm{L}^{1}$ - obtained through the condensation of 4-aminoantipyrine with furfuraldehyde and $\mathrm{HL}^{2}-$ derived from 2-aminophenol and vanillin) were synthesized. They were characterized using analytical and spectral techniques. Cyclic voltammogram of complexes in DMSO solution at $300 \mathrm{~K}$ was recorded and their salient features were summarized. The X-band ESR spectrum of the copper complex in DMSO solution at 300 and $77 \mathrm{~K}$ was recorded. All the synthesized metal complexes were screened for their in vitro antimicrobial activity against of bacteria and fungi by disc diffusion method. Comparative study of inhibition values of the Schiff bases and their complexes indicate that the complexes exhibit higher antimicrobial activity than the free ligands. The interaction of metal complexes with CT-DNA was investigated by UV-Vis., cyclic voltammetry, viscosity and thermal denaturation studies. The nuclease activities of the complexes were assayed on pUC19 DNA using gel electrophoreses in the presence of $\mathrm{H}_{2} \mathrm{O}_{2}$. All the metal complexes cleave the pUC19 DNA in presence of $\mathrm{H}_{2} \mathrm{O}_{2}$. The solvatochromic behaviour of complexes was discussed using UV-Vis., spectrophotometry in various solvents. Superoxide dismutase activity of these complexes has also been studied.

Copy Right, IJAR, 2016,. All rights reserved.

\section{Introduction:-}

The metal complexes containing multidentate aromatic ligands are very important due to their capacity for binding and cleaving DNA under physiological conditions (Akdi et al., 2005). These efforts stem from the development of novel chemotherapeutics and highly sensitive diagnostic agents (Ji et al., 2001). Metal complexes are known to bind to DNA in either a non-covalent or a covalent fashion. In covalent binding, the labile ligands of the complexes are replaced by a nitrogen base of DNA such as guanine $\mathrm{N}_{7}$ (Kumar et al., 2008). Non-covalent DNA interactions include three binding modes: intercalation, groove (surface) binding and external static electronic effects, along the outside of the DNA helix (Pyle et al., 1989).

Antipyrine and its derivatives exhibit a wide range of biological activities and applications (Abd El Rehim et al., 2001; Ismail, 2005; Yadav et al., 2003). Antipyrine showed minimal protein binding, and its rapidly and completely absorbed from the gastrointestinal tract and extensively metabolized by the cytochrome $\mathrm{P}_{450}$ liver 
enzymes (Poulsen and Loft, 1998). Estimates of half-life and systemic clearance of antipyrine have been used for the in vivo assessment of hepatic drug oxidation in different species (Koning and Cantilena, 1994). Schiff base derivatives have demonstrated significant biological activities and new examples have been tested for their antitumor, antimicrobial and antiviral activities (Sun et al., 2006).

Superoxide dismutases (SODs) are metalloenzymes that catalyze the conversion of superoxide radical $\left(\mathrm{O}_{2}{ }^{-{ }^{-}}\right)$to oxygen $\left(\mathrm{O}_{2}\right)$ and hydrogen peroxide $\left(\mathrm{H}_{2} \mathrm{O}_{2}\right)$ at rates approaching the diffusion controlled limit. Therefore, they play a crucial role in pro tecting biological systems against the damage mediated by this deleterious radical (Miller and Sorkin, 1997; Miller, 2003: Hassan and Fridovich, 1981; Fridovich, 1995). The known SOD enzymes, CuZn(SOD) is the most efficient catalytic species. It catalysed the disproportionation of the cytotoxic superoxide radical $\mathrm{O}_{2}{ }^{--}$, to oxygen and hydrogen peroxide, through one electron redox cycle involving its copper centre. It is known since three decades ago that cancer cells have less than normal SOD activity and the treatment with bovine native CuZn(SOD) decreased the growth of several solid tumours (Oberly and Buettner, 1979). Furthermore, low molecular weight compounds with superoxide dismutase mimetic activity have potential use as antioxidant pharmaceuticals in the treatment or prevention of several diseases related with the overproduction of an undesired $\mathrm{O}_{2}{ }^{-}$. In particular, some copper complexes with SOD mimetic activity have demonstrated to possess antiinflammatory activity, anticarcinogenic and antimutagenic effects (Oberley, 2005; Mitrunen et al., 2001)

The investigation of solvatochromic behaviour (El-Ayaan et al., 2001) of mixed ligand metal complexes has been of importance, because it provides a quantitative approach to recognize the solvent behavior and the role of the solvent in physico-chemical studies (Marcus, 1993). Moreover, it is very helpful for developing environmental sensor materials, which are chromotropic and exhibit color change when exposed to solvent or pollutant molecules (Sone and Fukuda, 1987).

In the present study, we have reported the solvatochromism, biochemical, DNA binding and clevage studies of mixed-ligand complexes. They were characterized using analytical and spectral techniques. The biochemical studies of complexes were also performed.

\section{Materials and Methods:- Materials:-}

All chemicals used in the present work viz, 4-aminoantipyrine, furfuraldehyde, 2-aminophenol, vanillin, $\mathrm{Fe}(\mathrm{III})$, $\mathrm{Co}(\mathrm{II}), \mathrm{Cu}$ (II), $\mathrm{Ni}$ (II) and $\mathrm{Zn}$ (II) chlorides were of analytical reagent grade (Merck, Germany). The solvents used in the synthesis of the ligands and metal complexes were distilled before use. Calf thymus DNA, pUC19 purchased from Genie Biolab, Bangalore, India.

\section{Instrumentation:-}

The elemental analysis was performed using Elementar Vario EL III Carlo Erba 1108. The amount of metal present in the metal complexes was estimated using ammonium oxalate method. IR spectra of the Schiff base ligands and their metal complexes were recorded on Perkin- Elmer FT-IR 783 Spectrophotometer in 4000-300 $\mathrm{cm}^{-1}$ range using $\mathrm{KBr}$ disc. ${ }^{1} \mathrm{H}-\mathrm{NMR}$ spectra were recorded on a Bruker Avance Dry $300 \mathrm{MHz}$ FT-NMR Spectrometer in DMSO with TMS as the internal reference. The FAB mass spectrum of the Schiff base ligands and their complexes were recorded on a JEOL SX 102/DA-6000 mass spectrometer / data system using argon / xenon $(6 \mathrm{kV}, 10 \mathrm{~mA})$ as the FAB gas. ESR spectra of the mixed ligand copper complex was recorded on a Varian E 112 EPR Spectrometer in DMSO solution both at room temperature $(300 \mathrm{~K})$ and at liquid nitrogen temperature $(77 \mathrm{~K})$ using TCNE (tetracyanoethylene) as the $\mathrm{g}$ marker. Electronic absorption spectra of the mixed ligand complexes were recorded in DMSO using a Systronics 2201 double beam UV- Vis., spectrophotometer. Molar conductance of the metal complexes was measured in DMSO solution using a coronation digital conductivity meter. The magnetic susceptibility values were calculated using the relation $\mu_{\text {eff }}=2.83\left(\chi_{\mathrm{m}} . \mathrm{T}\right)^{1 / 2} \mathrm{BM}$. The diamagnetic corrections were made by Pascal's constant and $\mathrm{Hg}\left[\mathrm{Co}(\mathrm{SCN})_{4}\right]$ was used as a calibrant. Electrochemical experiments were performed on a CHI 604D electrochemical analysis system with a three-electrode system consisted a glassy carbon working electrode, Pt wire auxiliary electrode and $\mathrm{Ag} / \mathrm{AgCl}$ reference electrode. Tetrabutylammoniumperchlorate (TBAP) was used as the supporting electrolyte. All solutions were purged with $\mathrm{N}_{2}$ for 30 min prior to each set of experiments. Calf thymus DNA, pUC19 DNA was purchased from Bangalore Genei (India). Tris-HCl buffer solution used for binding studies was prepared using deionised double distilled water. 


\section{Preparation:- \\ Preparation of ligands:-}

$\mathrm{L}^{1}$ : The ligand $\left(\mathrm{L}^{1}\right)$ was prepared as reported previously (Ismail et al., 1997)

The Schiff base $\mathrm{L}^{1}$ was prepared by a dropwise addition, with stirring, of ethanolic solution of furfuraldehyde, to an ethanolic solution of 4-aminoantipyrine respectively. The reaction mixture was refluxed on a water bath for 1-2 $\mathrm{h}$. On cooling, the solid products were separated and filtered. Both Schiff Physical measurements bases were recrystallized from ethanol and dried in vacuo over $\mathrm{P}_{4} \mathrm{O}_{10}$, to yield yellow crystals.

$\mathrm{HL}^{2}$ :

The ligand $\left(\mathrm{HL}^{2}\right)$ was prepared by the condensation of equimolar ratio of 2- aminophenol with vanillin in ethanolic medium. The resulting reaction mixture was stirred well, refluxed for 3-6 h and then allowed to cool overnight. The coloured solid precipitate of Schiff base obtained was filtered, washed with cold ethanol and dried in vacuum.

\section{Preparation of metal complexes:-}

An ethanolic solution of metal(II) $\left(\mathrm{M}=\mathrm{FeCl}_{3} \cdot 6 \mathrm{H}_{2} \mathrm{O}, \mathrm{CoCl}_{2} \cdot 6 \mathrm{H}_{2} \mathrm{O}, \mathrm{NiCl}_{2} \cdot 6 \mathrm{H}_{2} \mathrm{O}, \mathrm{CuCl}_{2} \cdot 2 \mathrm{H}_{2} \mathrm{O} \& \mathrm{ZnCl}_{2}\right)(1 \mathrm{mM})$ was stirred with an ethanolic solution of ligands $\left(\mathrm{L}^{1} \& \mathrm{HL}^{2}\right)(1 \mathrm{mM})$ and the resultant mixture was refluxed for ca. 6-8 $\mathrm{h}$. Then the volume of solution was reduced to one-third on a water bath. The solid complex precipitated was filtered, washed thoroughly with ethanol and dried in vacuum.

Schematic route for synthesis of Schiff base ligands and their metal complexes is given in Scheme 1.

\section{DNA-binding assay:-}

Interaction of the complex with calf thymus DNA has been studied by recording electronic absorption spectra. A solution of CT-DNA in $5 \mathrm{mM}$ Tris- $\mathrm{HCl} / 50 \mathrm{mM} \mathrm{NaCl}(\mathrm{pH} 7.0)$ gave a ratio of UV absorbance at 260 and $280 \mathrm{~nm}$ $\left(\mathrm{A}_{260} / \mathrm{A}_{280}\right)$ of 1.8-1.9, indicating that the DNA is free of proteins. A concentrated stock solution of DNA was prepared in $5 \mathrm{mM}$ Tris- $\mathrm{HCl} / 50 \mathrm{mM} \mathrm{NaCl}$ in water at $\mathrm{pH} 7.0$ and the concentration of CT-DNA was determined per nucleotide by taking the absorption coefficient $\left(6600 \mathrm{dm}^{3} \mathrm{~mol}^{-1} \mathrm{~cm}^{-1}\right)$ at $260 \mathrm{~nm}$. Doubly distilled water was used to prepare buffer solutions. Solutions were prepared by mixing the complex and CT-DNA in DMF medium. After equilibrium is reached (ca. $5 \mathrm{~min}$ ) the spectra were recorded against an analogous blank solution containing the same concentration of DNA. UV spectral data were fitted into Eq. (1) to obtain the intrinsic binding constant $\left(\mathrm{K}_{\mathrm{b}}\right)$

$$
[D N A] /\left(\varepsilon_{\mathrm{a}-} \varepsilon_{\mathrm{f}}\right)=[\mathrm{DNA}] /\left(\varepsilon_{\mathrm{b}}-\varepsilon_{\mathrm{f}}\right)+\mathrm{K}_{\mathrm{b}}\left(\varepsilon_{\mathrm{b}}-\varepsilon_{\mathrm{f}}\right)
$$

where [DNA] is the concentration of DNA in base pairs, $\varepsilon_{\mathrm{a}}, \varepsilon_{\mathrm{b}}$ and $\varepsilon_{\mathrm{f}}$ are apparent extinction coefficient $\left(\mathrm{A}_{\mathrm{obs}} /[\mathrm{M}]\right)$, the extinction coefficient for the metal (M) complex in the fully bound form and the extinction coefficient for free metal (M), respectively. A plot of [DNA]/ $\left(\varepsilon_{\mathrm{a}}{ }^{-} \varepsilon_{\mathrm{f}}\right)$ versus [DNA] gave a slope of $1 /\left(\varepsilon_{\mathrm{b}}{ }^{-} \varepsilon_{\mathrm{f}}\right)$ and Y-intercept equal to $1 / \mathrm{K}_{\mathrm{b}}\left(\varepsilon_{\mathrm{b}}-\varepsilon_{\mathrm{f}}\right) ; \mathrm{K}_{\mathrm{b}}$ is the ratio of the intercept.

\section{Viscosity study:-}

Viscosity measurements at room temperature were carried on an Ostwald viscometer, immersed in a thermostated water-bath maintained at constant temperature at $25 \pm 0.1^{\circ} \mathrm{C}$. Each experiment was performed three times and an average flow time was calculated. Data were presented as $\left(\eta / \eta_{0}\right)$ versus binding ratio, where $\eta$ is the viscosity of DNA in presence of complex and $\eta_{0}$ is the viscosity of DNA alone.

\section{Thermal denaturation studies:-}

Melting studies were carried out by monitoring the absorption of CT- DNA at $260 \mathrm{~nm}$ various temperatures in the presence and absence of each complex. The temperature of the solution was increased by $1^{\circ} \mathrm{C} \min ^{-1}$. As such, the melting temperature $\left(\mathrm{T}_{\mathrm{m}}\right)$, at which $50 \%$ of double-stranded DNA becomes single-stranded occurred.

\section{DNA photocleavage experiments:-}

DNA photocleavage experiment was performed in a volume of $2 \mathrm{~mL}$ containing pUC19 DNA in $5 \mu \mathrm{M} / \mathrm{L}$ phosphate buffer contained $10 \mu \mathrm{M} / \mathrm{L} \mathrm{NaCl}, \mathrm{pH} 7.4$, in the presence of different concentrations (50-100 $\mu \mathrm{M} / \mathrm{L}$ ) of complexes. Immediately prior to irradiating the samples with UV light, $\mathrm{H}_{2} \mathrm{O}_{2}$ was added to a final concentration of 2.5

$\mu \mathrm{M} / \mathrm{L}$. The reaction volumes were held in caps of polyethylene microcentrifuge tubes, which were placed directly on the surface of a trans-illuminator $(8000 \mathrm{~mW} / \mathrm{cm})$ at $360 \mathrm{~nm}$. The samples were irradiated for $30 \mathrm{~min}$ at room 
temperature. After irradiation, $0.5 \mathrm{~mL}$ of a mixture containing $0.25 \%$ bromophenol blue, $0.25 \%$ xylene cyanol FF and $30 \%$ glycerol was added to the irradiated solution. The samples were then analyzed by electrophoresis on a $1 \%$ agarose horizontal slab gel in Tris-borate buffer $(45 \mu \mathrm{M} / \mathrm{L}$ Tris-borate, $1 \mu \mathrm{M} / \mathrm{L}$ EDTA). Untreated pUC19 DNA was maintained as a control in each run of gel electrophoresis, which was carried out at $50 \mathrm{~V}$ for $2.5 \mathrm{~h}$. Gel was stained with ethidium bromide $(1 \mu \mathrm{g} / \mathrm{mL})$ and photographed under UV light (Dhar et al., 2003).

\section{Antimicrobial activity:-}

The in vitro evaluation of antimicrobial activity was carried out. The synthesized compounds were tested against some fungi and bacteria to provide minimum inhibitory concentration (MIC) for each compound. MIC is the lowest concentration of solution to inhibit the growth of a test organism. The in vitro biological screening effects of the investigated compounds were tested against the bacterial species Staphylococcus aureus, Escherichia coli, Klebsiella pneumoniae, Proteus vulgaris and Pseudomonas aeruginosa and fungal species Aspergillus niger, Rhizopus stolonifer, Aspergillus flavus, Rhizoctonia bataicola and Candida albicans by disc diffusion method. Pencillin Ampicillin, Vancomycin, Ofloxacin were used as standards for antibacterial activity. Nystatin, Kctoconazole, Clotrimazole, was used as standard for antifungal activity. The test organisms were grown on nutrient agar medium in petri plates. The compounds were prepared in DMSO and soaked in a filter paper disc of $5 \mathrm{~mm}$ diameter and $1 \mathrm{~mm}$ thickness. The compounds were prepared in DMSO and soaked in a filter paper disc of $5 \mathrm{~mm}$ diameter and $1 \mathrm{~mm}$ thickness. The discs were placed on the previously seeded plates and incubated at $37^{\circ} \mathrm{C}$ and the diameter of inhibition zone around each disc was measured after $24 \mathrm{~h}$ for antibacterial and $72 \mathrm{~h}$ for antifungal activities. The minimum inhibitory concentration (MIC) was determined by serial dilution technique.

\section{Superoxide dismutase (SOD) activity:-}

In vitro SOD activity was measured using alkaline DMSO as a source of superoxide radical ion $\left(\mathrm{O}_{2}{ }^{-}\right)$and nitrobluetetrazolium (NBT) as $\mathrm{O}_{2}{ }^{--}$scavenger (Bhirud and Shrivastava, 1991). In general, $400 \mu \mathrm{L}$ of the sample to be assayed was added to a solution containing $2.1 \mathrm{~mL}$ of $0.2 \mathrm{M}$ potassium phosphate buffer (pH 7.8) and $1 \mathrm{~mL}$ of 56 $\mu \mathrm{M}$ NBT. The tubes were kept in ice for $20 \mathrm{~min}$ and then $1.5 \mathrm{~mL}$ of alkaline DMSO solution was added while stirring. The absorbance was then monitored at $560 \mathrm{~nm}$ against a sample prepared under similar condition except that $\mathrm{NaOH}$ was absent in DMSO. The \% inhibition ( $\eta$ ) of NBT reduction was calculated using following equation

$(\%$ Inhibition of NBT reduction $)=\left(1-\mathrm{k}^{\prime} / \mathrm{k}\right) \times 100$

where, $\mathrm{k}^{\prime}$ and $\mathrm{k}$ represent the slopes of the straight line of absorbance values as a function of time in presence and in absence of SOD mimic or a model compound, respectively. $\mathrm{IC}_{50}$ value of the complex was determined by plotting the graph of percentage inhibition of NBT reduction against increase in the concentration of complex. Concentration of the complex which causes $50 \%$ inhibition of NBT reduction is reported as $\mathrm{IC}_{50}$.

\section{Results and Discussion:-}

The analytical data and physical properties of the Schiff base ligands and its complexes are listed in Table 1. The Schiff base ligands were soluble in common organic solvents. The elemental analysis data (Table 1) confirmed that the complexes have a 1:1 molar ratio between the metal and the Schiff base ligands. The conductance (Table 1) values in the range of $9-51\left(\Omega^{-1} \mathrm{~cm}^{2} \mathrm{~mol}^{-1}\right)$, which indicate that all the complexes are in 1:1 electrolytic in nature except iron complex (non electrolytic in nature).

\section{${ }^{1}$ H NMR Spectra:-}

The ligand $\left(\mathrm{L}^{1}\right)$ shows the following signals and their assignments are given below: phenyl multiplet at $7.3-7.5 \delta$ $(5 \mathrm{H}),-\mathrm{CH}=\mathrm{N}$ at 7.9 (due to furfuryl moiety), $-\mathrm{C}^{-\mathrm{CH}_{3}}$ at $2.4 \delta, \mathrm{N}_{-} \mathrm{CH}_{3}$ at $3.2 \delta$, furfuryl protons at 6.5-7.7 $\delta$. The ligand $\left(\mathrm{HL}^{2}\right)$ shows the following signals are assigned as: phenyl multiplet at $6.9-7.5 \delta(7 \mathrm{H}),-\mathrm{O}-\mathrm{CH}_{3}$ at $3.8 \delta$, - C$\mathrm{OH}$ at $5.3 \delta(\mathrm{s}, 1 \mathrm{H}),-\mathrm{CH}=\mathrm{N}$ at $8.6 \delta$ (due to phenyl moiety) and $-\mathrm{OH}$ at $7.3 \mathrm{ppm}$ (phenyl moiety). The azomethine proton $(-\mathrm{CH}=\mathrm{N})$ signal in the spectrum of zinc complex is shifted down field (7.8 and $8.5 \mathrm{ppm})$ compared to the free ligands, suggesting deshielding of azomethine group due to the coordination with metal ion. The phenolic $\mathrm{OH}$ proton in the ligand $\left(\mathrm{HL}^{2}\right)$ disappeared in the zinc complex suggested that $-\mathrm{OH}$ proton involved in coordination. The ${ }^{1}$ H NMR spectrum of Zinc complex was shown in fig 1. All the protons were found to be in the similar regions.

\section{IR spectra:-}

In order to study the binding mode of the Schiff base to the metal complexes, the IR spectra of the free ligands were compared with the spectra of the complexes. The absorption band at $1717 \mathrm{~cm}^{-1}$ is assigned $v(\mathrm{C}=\mathrm{O})$ in $\mathrm{L}^{1}$ free ligand. 
The shift of bands to lower wave number $10-35 \mathrm{~cm}^{-1}$ in the spectra of all complexes suggested that the involvement of the pyrazolone oxygen in chelation.

The strong absorption bands located at 1616 and $1622 \mathrm{~cm}^{-1}$ in the spectrum of the free ligands $\mathrm{L}^{1}$ and $\mathrm{HL}^{2}$ are attributed to $v(-\mathrm{CH}=\mathrm{N})$ vibrations. These bands are shifted (by $\sim 10-40 \mathrm{~cm}^{-1}$ ) towards lower frequencies in the spectra of all the complexes, which clearly suggested that complexation has taken place through the nitrogen atom of azomethine group.

The IR spectra of the $\mathrm{HL}^{2}$ ligands shows strong bands in the 3265-3279 $\mathrm{cm}^{-1}$ (2-methoxy phenol moiety) and 3346 $3431 \mathrm{~cm}^{-1}$ (phenyl moiety) region, assigned to phenolic -OH group. The disappearance of $3346-3431 \mathrm{~cm}^{-1}$ band in the spectra of the complexes indicates the deprotonation of the -OH group upon coordination. The IR spectra of the metal complexes also show some new bands in the $545-528 \mathrm{~cm}^{-1}$ and $443-425 \mathrm{~cm}^{-1}$ regions, which may probably due to the formation of $v(\mathrm{M}-\mathrm{O})$ and $v(\mathrm{M}-\mathrm{N})$ bands respectively. In the case of $\mathrm{Fe}(\mathrm{III})$ complex, the weak band appearance at $345 \mathrm{~cm}^{-1}$ is probably due to the formation of $\mathrm{Fe}-\mathrm{Cl}$ bond. IR spectral data of the ligands (L $\mathrm{L}^{1}$ (2a) \& $\mathrm{HL}^{2}(2 \mathrm{~b})$ ) and copper complex (Fig 2c) and presented in Table 2.

\section{Electronic absorption spectra:-}

The electronic absorption spectral data of the ligands and their complexes were recorded in DMSO and presented in Table 3. In electronic spectra of metal complexes the wide range of bands are due to transition of $-\mathrm{CH}=\mathrm{N}-$, charge transfer results from electrons interaction between the metal and the ligand which involves either a metal to ligand or ligand to metal electron transfer (Tas et al., 2006).

The electronic spectrum of free Schiff base ligands $\mathrm{L}^{1}, \mathrm{HL}^{2}$ shows a broad band at 265 and $341 \mathrm{~nm}$, which is assigned to the $\pi-\pi^{*}$ and $n-\pi^{*}$ transition of the azomethine $(>\mathrm{C}=\mathrm{N}-$ ) chromophore. On complexation this band was shifted to lower wavelengths, suggesting the coordination of azomethine nitrogen to the central metal ion.

The electronic spectrum of $\mathrm{Fe}(\mathrm{III})$ complex exhibits bands at $354 \mathrm{~nm}$ and $792 \mathrm{~nm}$ are attributable to $\mathrm{n}-\pi^{*}$ and ${ }^{6} \mathrm{~A}_{1 \mathrm{~g}}$ $\rightarrow{ }^{4} \mathrm{~T}_{\mathrm{g}}(\mathrm{G})$, respectively. These transitions are assigned for octahedral Fe(III) complexes. The electronic transitions together with the magnetic moment value of $5.92 \mathrm{BM}$ suggested high-spin octahedral geometry for the $\mathrm{Fe}(\mathrm{III})$ complex.

The spectrum for $\mathrm{Co}(\mathrm{II})$ complex shows a bands at $351 \mathrm{~nm}$ and $538 \mathrm{~nm}$ may be assigned to $\mathrm{n}-\pi^{*}$ and ${ }^{1} \mathrm{~A}_{1 \mathrm{~g}} \rightarrow{ }^{1} \mathrm{~B}_{\mathrm{g}}$ respectively, in square planar. Together with the magnetic moment value of $3.91 \mathrm{BM}$, a square planar geometry for the Co(II) complex was assigned.

The electronic spectrum of the nickel complex shows d-d bands at $348 \mathrm{~nm}$ and $576 \mathrm{~nm}$ which are assigned as $\mathrm{n}-\pi^{*}$ and ${ }^{1} \mathrm{~A}_{1 \mathrm{~g}} \rightarrow{ }^{1} \mathrm{~B}_{1 \mathrm{~g}}$ transition indicates that the square planar geometry (Dutt, 1992). This complex is diamagnetic in nature. Therefore a square-planar geometry has been suggested.

In copper complex exhibits band at $254 \mathrm{~nm}$ and $552 \mathrm{~nm}$ assigned to $\mathrm{n}-\pi^{*}$ and ${ }^{2} \mathrm{~B}_{1 \mathrm{~g}} \rightarrow{ }^{2} \mathrm{~A}_{1 \mathrm{~g}}$ transitions characteristic of a square plannar geometry with $\mathrm{d}_{\mathrm{x} 2-\mathrm{y} 2}$ ground state (Lever, 1994). These data and the magnetic moment value of $1.83 \mathrm{BM}$ suggest square-planar geometry around $\mathrm{Cu}(\mathrm{II})$.

$\mathrm{Zn}$ (II) is a $\mathrm{d}^{10}$ metal ion, no band is expected in the visible region and is also found as a diamagnetic complex, as expected. However, a strong band observed at $451 \mathrm{~nm}$ is assignable to the $\mathrm{L} \rightarrow \mathrm{M}$ charge transfer transition (Temel et al., 2002) which is compatible with this complex having a square planar geometry.

\section{ESR spectra:-}

ESR spectrum of the copper complex was recorded in DMSO at 300 and 77K (fig 3). The spectrum at $300 \mathrm{~K}$ shows ne intense absorption band at high field, which is isotropic due to tumbling motion of the molecules. The observed trend of $g_{\|}(2.24)>g_{\perp}(2.05)>g_{e}(2.0023)$ describes the axial symmetry with the unpaired electron residing in the $\mathrm{d}_{\mathrm{x} 2-\mathrm{y} 2}$ orbital (Hathaway and Billing 1970). The value of $\mathrm{g}_{\|}<2.2$ in the present copper complex gives a clear indication of covalent character of the metal-ligand bond and delocalisation of the unpaired electron into the ligand.

Molecular orbital coefficients $\alpha^{2}$ (covalent inplane $\sigma$-bonding), $\beta^{2}$ (covalent in-plane $\pi$-bonding) and $\gamma^{2}$ (out-plane $\pi$ -bonding) were calculated using the following Eqs. (3)- (5). 
$\alpha^{2}=\left(\mathrm{A}_{\|} / \mathrm{p}\right)+\left(\mathrm{g}_{\|}-2.0027\right)+3 / 7\left(\mathrm{~g}_{\perp}-2.0023\right)+0.04$

$\beta^{2}=\left(\mathrm{g}_{\|}-2.0027\right) \mathrm{E} /-8 \lambda \alpha^{2}$

$\gamma^{2}=\left(\mathrm{g}_{\|}-2.0027\right) \mathrm{E} /-2 \lambda \alpha^{2}$

The $\alpha^{2}$ (0.75) value for the complex supports its covalent nature of the bonding. Hathaway [28] pointed out that for the pure bonding $\mathrm{K}_{\|}>\mathrm{K}_{\perp} \approx 0.77$ and for in-plane

$\pi$ bonding $\mathrm{K}_{\|}<\mathrm{K}_{\perp}$, while for out-of-plane $\pi$ bonding $\mathrm{K}_{\perp}<\mathrm{K}_{\|}$the following simplified expressions were used to calculate $\mathrm{K}_{\|}$and $\mathrm{K}_{\perp}$.

$\mathrm{K}_{\|}=\alpha^{2} \beta^{2}$

$\mathrm{K} \perp=\alpha^{2} \gamma^{2}$

For the present complex, the observed order $\mathrm{K}_{\|}(0.98)>\mathrm{K} \perp(0.61)$ implies a greater contribution from out-of plane $\Pi$ -bonding than from in in-plane $\Pi$-bonding in metal-ligand $\Pi$ bonding.

The $A_{\|}$and $A \perp$ values in the order: $A_{\|}(154)>A_{\perp}(36)$ also indicate that the complex has square planar geometry. The empirical factor $\mathrm{f}=\mathrm{g}_{/ /} / \mathrm{A}_{/ /} \mathrm{cm}^{-1}$ is an index of tetragonal distortion. Values of this factor may vary from 105 to 135 for small to extreme distortions in square planar complexes and it depends on the nature of the coordinated atoms (Pogni et al., 2000). The f values of copper complexes found to be in the range 145 (table 4) indicating significant distortion from planarity.

\section{Mass spectra:-}

The FAB mass spectra of the Schiff bases and their corresponding metal complexes were recorded and compared their stoichiometry compositions. The Schiff base ligands $\mathrm{L}^{1} \& \mathrm{HL}^{2}$ shows a molecular ion peak at $\mathrm{m} / \mathrm{z}=281$ \& 243. The mass spectra of $\mathrm{Fe}$ (III), $\mathrm{Co}(\mathrm{II}), \mathrm{Ni}(\mathrm{II}), \mathrm{Cu}(\mathrm{II})$ and $\mathrm{Zn}$ (II) complexes show a molecular ion peak $\left(\mathrm{M}^{+}\right)$at $\mathrm{m} / \mathrm{z} 650,617,618,622$ and 624 respectively, the stoichiometry of the complexes as supported by the FAB mass spectra of other complexes. Elemental analysis values are in close agreement with the values calculated from molecular formula of these complexes, which is further supported by the FAB-mass studies of representative complexes.

\section{Solvatochromism:-}

The mixed ligand complexes are easily soluble in a wide range of organic solvents. The presence of a strong JohnTeller effect on the $\mathrm{Cu}$ (II) ions made them good solvatochromic probes. The electronic absorption spectra of the $\mathrm{Cu}$ (II) complexes are characterized by a broad structureless band in the visible region attributed to the promotion of an electron in the low-energy orbitals to the hole in $\mathrm{d}_{\mathrm{x} 2-\mathrm{y} 2}$ orbital of the $\mathrm{Cu}(\mathrm{II})$ ion $\left(\mathrm{d}^{9}\right)$. The visible spectral changes of these complexes in selected solvents are illustrated in Fig. 4 and $\lambda_{\max }$ values are presented in table 5 . The solvent effect on spectra resulting from electronic transitions, is primarily dependent on the chromophore and the nature of the transition $\left(\sigma \rightarrow \sigma^{*}, \mathrm{n} \rightarrow \sigma^{*}, \pi \rightarrow \pi^{*}, \mathrm{n} \rightarrow \pi^{*}\right.$, and charge transfer absorption). The electronic transitions of particular interest in this respect $\pi \rightarrow \pi^{*}, \mathrm{n} \rightarrow \pi^{*}$ and charge transfer absorptions. The color changes are attributed to the shift in the $\mathrm{d}-\mathrm{d}$ transition of the metal (II) ions as results of solvent-solute interactions. In all solvents, the observed $\lambda_{\max }$ values of the mixed ligand complexes appear in higher energy, it cause the mixed ligand complexes were interact more strongly with the solvent molecules. This strong salvation may be related to the high positive charge of the complexes, although steric and electronic factors are taking part in it.

\section{DNA Binding Studies:-}

The ability of complexes to bind the DNA was investigated by electronic absorption spectra, viscosity, thermal denaturation and cyclic voltammetry techniques.

\section{Absorption spectral features of DNA binding:-}

The DNA binding studies of the mixed ligand complexes were studied using absorption spectra. Metal Complex can binding with DNA through intercalation usually result in hypochromism and bathochromism. The extent of the hypochromism commonly parallels the intercalative binding strength (Tan et al., 2007). Hypochromism means the DNA binding mode of complex is electrostatic effect or intercalation which can stabilize the DNA duplex (Long and Barton 1990) and hyperchromism means the breakage of the secondary structure of DNA. So that the complex interacting with the secondary structure with calf thymus DNA resulting in its breakage and perturbation. After interaction with the base pairs of DNA, the $\pi \rightarrow \pi^{*}$ orbital of the bound ligand can couple with the $\pi$ orbital of the base pairs, due to the decrease $\pi \rightarrow \pi^{*}$ transition energy, which results in bathochromic shift (He et al., 1998). 
The absorption spectra of complexes in the absence and presence of CT-DNA of complexes are given in Fig. 5a-e. The binding results show that the bathochromic shift of 2-4 nm along with significant hypochromicity observed in addition of DNA to complex solution. When the amount of CT DNA is increased, decrease of intensity in the charge transfer band. These spectral characteristics suggest that the mixed ligand complexes most likely interact with DNA through a mode of stacking interaction between the ligand of the complexes and the base pairs of DNA. In order to compare the binding strength of the complexes, their intrinsic binding constants $\left(\mathrm{K}_{\mathrm{b}}\right)$ with CT-DNA have been determined from the decay of the absorbance.

The observed intrinsic binding constants $\mathrm{K}_{\mathrm{b}}$ of complexes are $4.5 \times 10^{4} \mathrm{M}^{-1}, 3.2 \times 10^{4} \mathrm{M}^{-1} 2.9 \times 10^{4} \mathrm{M}^{-1}, 4.5 \times 10^{4} \mathrm{M}^{-}$, $3.1 \times 10^{4} \mathrm{M}^{-1}$ respectively.

Viscosity measurements:-

The natures of binding modes of metal complexes with CT-DNA were determined by viscosity measurements. It was carried out by varying to the concentration added complexes. A classical intercalative mode was obtained on the basis of increase in viscosity of DNA solution due to an increase in separation of base pairs at the intercalation sites and increase in DNA length. However, a partial and / or nonclassical intercalation of ligand may bend (or kink) DNA helix, resulting under the same conditions. The plots of $\left(\eta / \eta_{0}\right)^{1 / 3} v_{s}$ [Complex]/[DNA], $\eta$ and $\eta_{0}$ are the relative viscosities of DNA in the presence and absence of compound, respectively) gives a measure of the viscosity changes. The effects of all the mixed ligand complexes on the viscosity of CT DNA are shown in Fig.6. The viscosity of DNA increased with the increment of each complexes and it is similar to the behavior of DNAintercalator $\left(\left[\mathrm{Ru}(\mathrm{bpy})_{2}(\mathrm{dppz})\right]^{2+}\right.$ (Wu et al., 2005).

\section{Thermal denaturation studies:-}

Thermal denaturation studies shows that the evidence for the ability of the complexes to stabilize the doublestranded DNA. When the temperature increases in solution, the double-stranded DNA is dissociates to single strands and generates a hypochromic effect on the absorption spectra of DNA bases $\left(\lambda_{\max }=260 \mathrm{~nm}\right)$. This transition process, the melting temperature $T_{m}$, is defined as the temperature where half of the total base pairs is unbonded, is introduced. According to the literatures (Waring, 1965; Kelly, et al., 1985; Neyhart et al.,1993), the intercalation of natural or synthesized organics and metallointercalators generally results in a considerable increase in melting temperature $\left(\mathrm{T}_{\mathrm{m}}\right)$. The thermal denaturation of DNA in the absence and presence of the complexes is shown in Fig. 7. $\mathrm{T}_{\mathrm{m}}$ of calf thymus DNA is found to be $75.8 \pm 0.2^{\circ} \mathrm{C}$. Under the same set of conditions, addition of metal complexes increased $\mathrm{T}_{\mathrm{m}}\left( \pm 1^{\circ} \mathrm{C}\right)$ by $4^{\circ} \mathrm{C}, 6^{\circ} \mathrm{C}$ and $5^{\circ} \mathrm{C}$, respectively, which indicate that these compounds stabilize the double helix of DNA. This method is easy to identify when more than one transition occurs (McCoubery et al., 1996). These variations in $T_{m}$ of calf thymus DNA strongly supported the intercalation of metal complex into the double helix DNA.

\section{DNA binding study:-}

In the cyclic voltammetric (CV) study, copper complexes in the presence and absence of CT DNA are shown in Fig.8. The absence of CT DNA, the Cu(II) complex shows a two peaks. The first peak Epa appeared at $1.01 \mathrm{~V}$ for $\mathrm{Cu}(\mathrm{II}) \rightarrow \mathrm{Cu}$ (III). These peaks exhibit an irreversible process. The second peak, Epc $=-0.901 \mathrm{~V}$ for $\mathrm{Cu}$ (III) to $\mathrm{Cu}(\mathrm{I})$ $\left[\mathrm{Epa}=-0.610 \mathrm{~V}, \Delta \mathrm{E}_{\mathrm{p}}=-0.291 \mathrm{~V}\right.$ and $\mathrm{E}_{1 / 2}=-0.755 \mathrm{~V}$. The $\mathrm{i}_{\mathrm{pa}} / \mathrm{i}_{\mathrm{pc}}$ ratios of these redox peak are 1.28 respectively, which indicate that the reaction of the $\mathrm{Cu}(\mathrm{II})$ complex exhibited quasi-reversible redox process. The presence of DNA in the solution at the same concentration of $\mathrm{Cu}$ (II) complex causes negative shift in $\mathrm{E}_{1 / 2}$ and a decrease in $\Delta \mathrm{Ep}$, which indicate that the $\mathrm{Cu}(\mathrm{II})$ complex had interacted with DNA. The value of $i_{\mathrm{pc}} / \mathrm{i}_{\mathrm{pa}}$ also decreases with the increase of DNA concentration. The decrease in peak currents can be explained in terms of an equilibrium mixture of free and DNA- bound $\mathrm{Cu}$ (II) complex to the electrode surface. All the other complexes exhibited quasi reversible peaks. Electrochemical parameters for the mixed ligand complexes on interaction with CT DNA are shown in table 6. These results clearly suggest that copper complex binds to CT DNA through intercalating way.

\section{Nuclease activity:-}

Supercoiled plasmid DNA cleavage by the metal complexes was studied in the presence of $\mathrm{H}_{2} \mathrm{O}_{2}$. We found that the supercoiled DNA (form I) was cleaved after 1 and $2 \mathrm{~h}$. Gel electrophoresis experiments were performed using pUC19 DNA with ligand, complexes in presence and absence of $\mathrm{H}_{2} \mathrm{O}_{2}$. In the present study, pUC19 DNA gel electrophoresis experiment was conducted at $37^{\circ} \mathrm{C}$ using the presence of $\mathrm{H}_{2} \mathrm{O}_{2}$ as an oxidant. DNA cleavage was analyzed by monitoring the conversion of super coiled DNA (Form I) to nicked DNA (Form II) and linear DNA (Form III) in the presence of oxidant $\mathrm{H}_{2} \mathrm{O}_{2}$ (Fig 9). The intensity of peak gave information about the complete 
conversion of circular into linear form. The results indicate that all the complexes can interact with pUC19 DNA in the presence of $\mathrm{H}_{2} \mathrm{O}_{2}$. However, $\mathrm{Fe}$ (III) complex can cleave DNA effectively as compared to other complexes due to disappearance of peak in the fig.9. In the case of $\mathrm{Cu}$ (II) complex, showed a slightly higher activity than $\mathrm{Ni}(\mathrm{II})$ and Co(II) complexes,respectively. The $\mathrm{Zn}$ (II) complex exhibited very low DNA cleavage efficiency as compared to other complexes. The higher DNA cleavage efficiency is mainly due to redox nature of complexes. It can catalyze the production of highly reactive hydroxyl radicals. It is evident that the complexes cleave DNA more effectively in the presence of oxidant. These hydroxyl radicals participate in the oxidation of the deoxyribose moiety, followed by the hydrolytic cleavage of the sugar-phosphate backbone (Babu et al., 2007).

\section{Superoxide dismutase (SOD) mimic activities:-}

The SOD activities of complexes were investigated by NBT assay. Copper gives good SOD activity, although it structure is totally unrelated with native enzyme. The ping-pong mechanism of SOD activity is given in Eqs. (8) and (9).
$\mathrm{Cu}^{2+}+\mathrm{O}_{2}^{-\cdot} \rightarrow \mathrm{Cu}^{+}+\mathrm{O}_{2}$
$\mathrm{Cu}^{+}+\mathrm{O}_{2}{ }^{-}+2 \mathrm{H}^{+} \rightarrow \mathrm{Cu}^{2+}+\mathrm{H}_{2} \mathrm{O}_{2}$

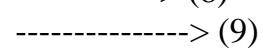

Fig. 10 represents plot of percentage of inhibiting NBT reduction with an increase in the concentration of complexes. Fig 11 represents plot of absorbance values against time (t) of copper complex. The percentage of inhibition at various concentrations of the copper complex as a function of time is calculated by measuring the absorbance at $560 \mathrm{~nm}$, and

the results are plotted to give a straight line. The $\mathrm{Cu}(\mathrm{II})$ complexes showed SOD-like activity which was evaluated by the scavenger concentration causes $50 \%$ inhibition in the detector formation, $\mathrm{IC}_{50}$. The $\mathrm{IC}_{50}$ values of the $\mathrm{Cu}$ (II) complexes are better than other complexes. The observed results showed that the superoxide scavenging properties and oxidative behavior of mixed ligand complexes were identical to those of complexes support the above mechanism.

\section{Step 1:-}


Step 2:-

$\left(\mathrm{HL}^{2}\right)$ 
Step 3:-

$\mathrm{M}=\mathrm{Cu}(\mathrm{II}), \mathrm{Ni}(\mathrm{II}), \mathrm{Co}(\mathrm{II})$ and $\mathrm{Zn}(\mathrm{II})$ 
Scheme 1:- Schematic route for synthesis of Schiff base ligands and its metal complexes. 

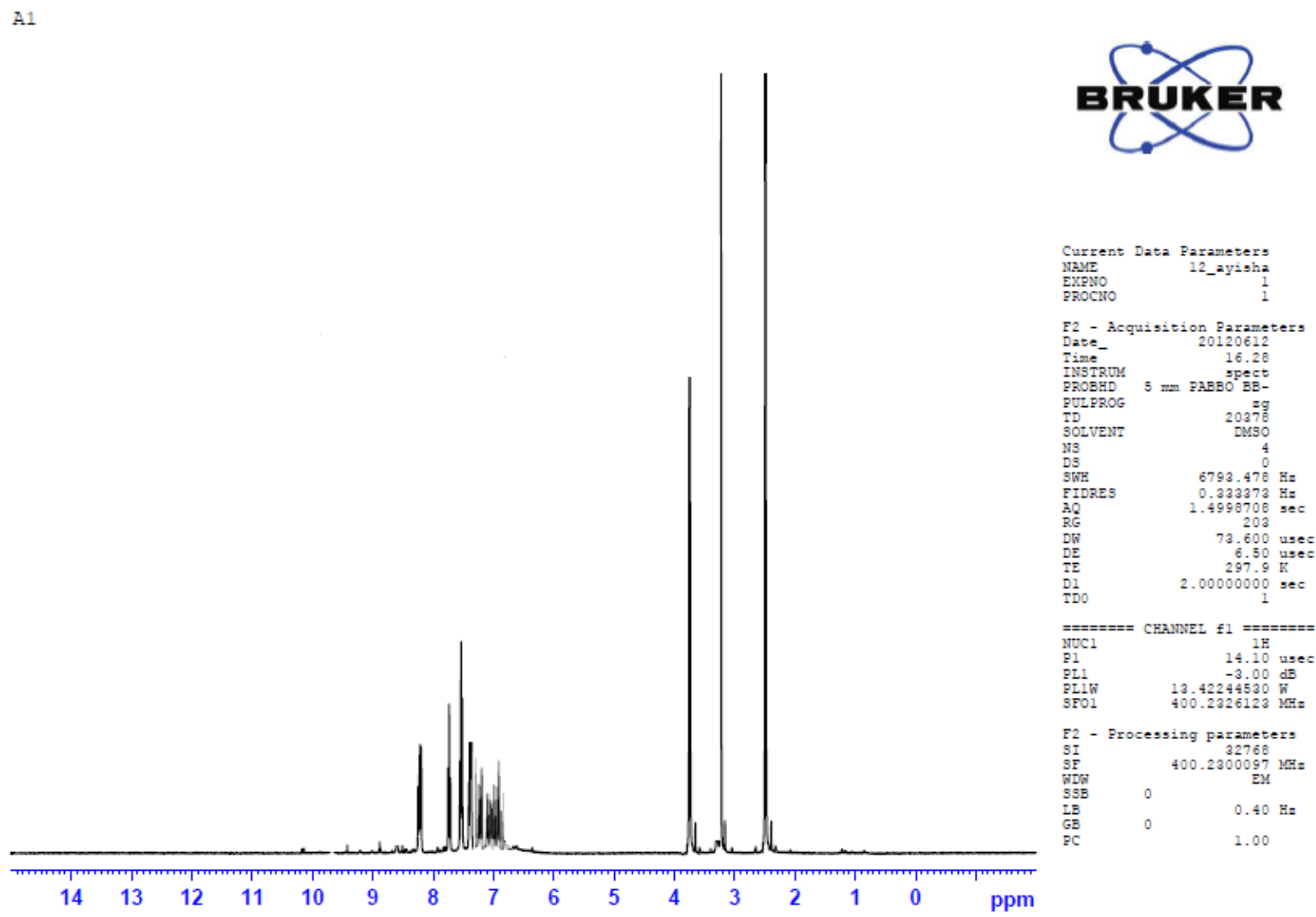

Fig. 1:- ${ }^{1} \mathrm{H}-\mathrm{NMR}$ spectrum for zinc complex.

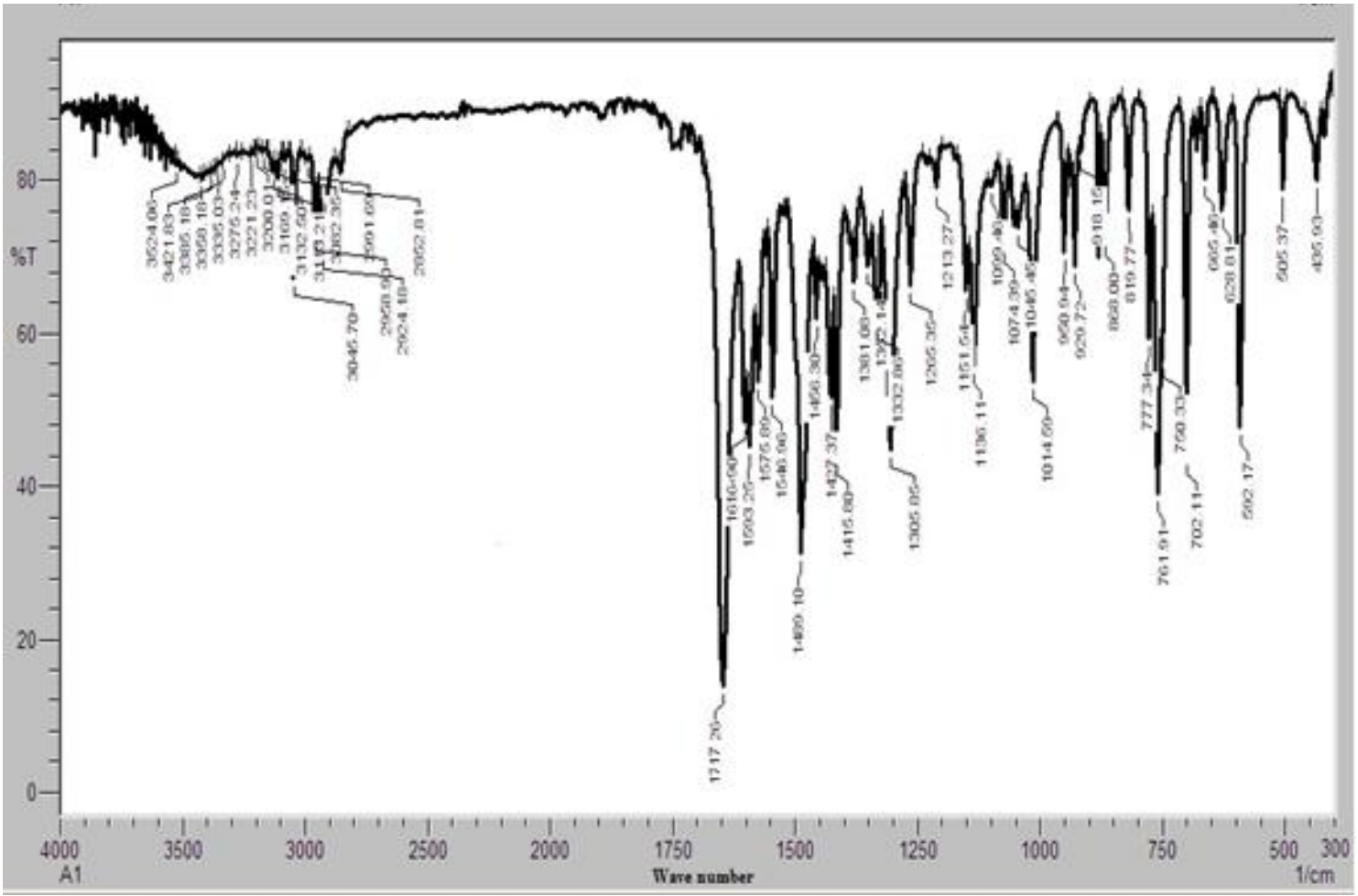

Fig 2a:- 


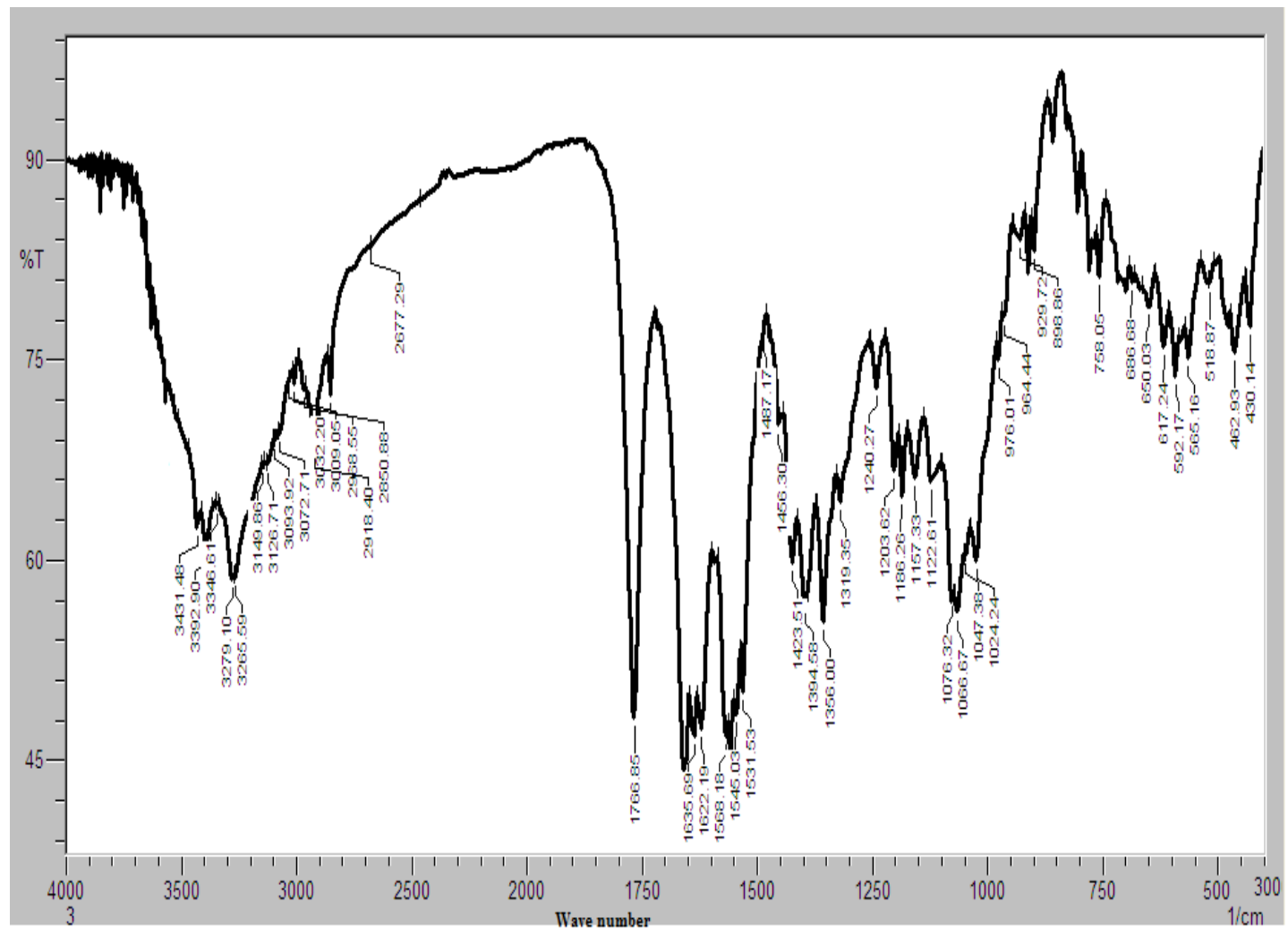

Fig 2b:-

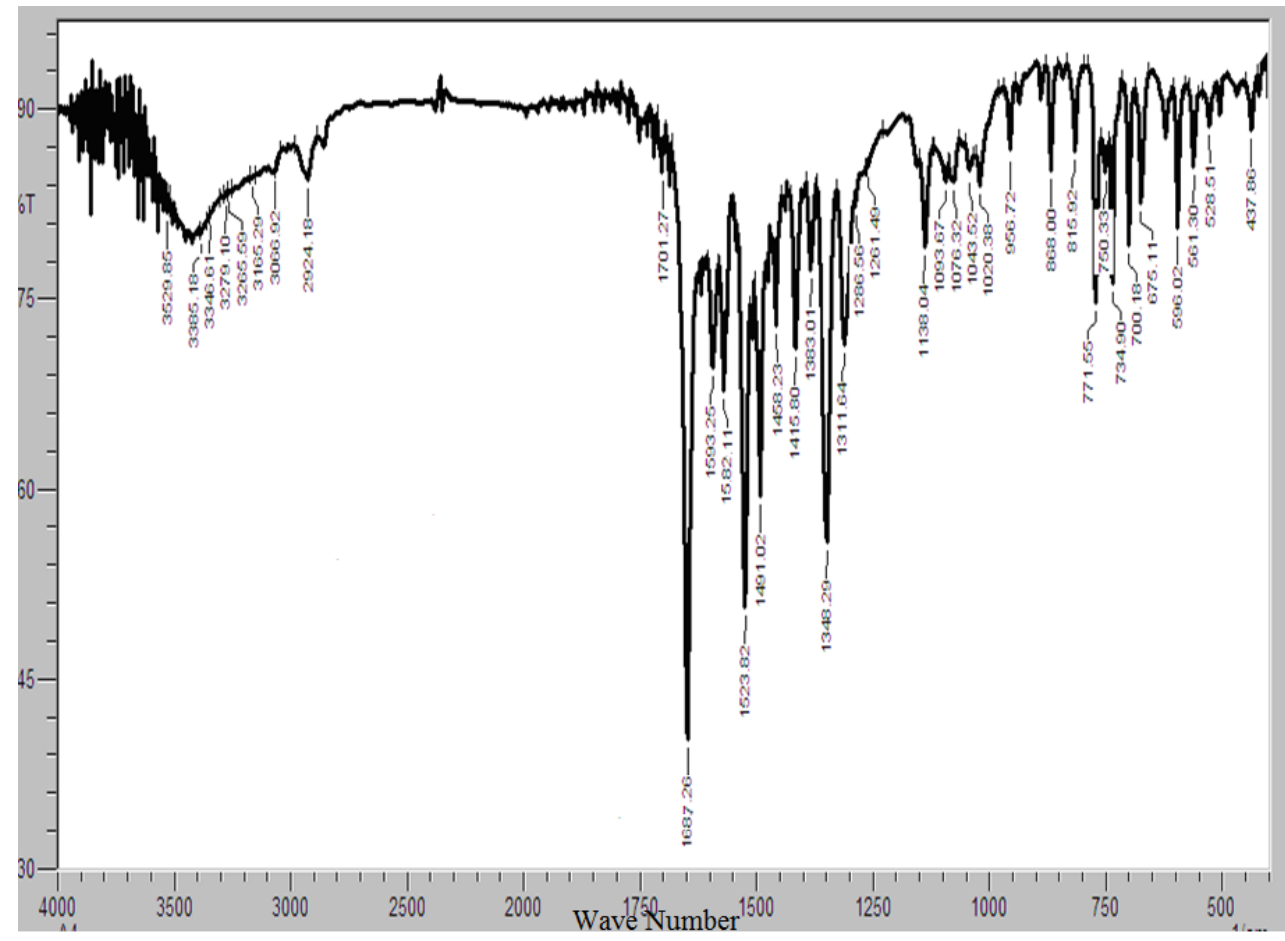

Fig 2c:-

Fig. 2a c:- IR spectrum of ligands $\left(\mathrm{L}^{1}(2 \mathrm{a}) \& \mathrm{HL}^{2}(2 \mathrm{~b})\right)$ and copper complex $(2 \mathrm{c})$. 

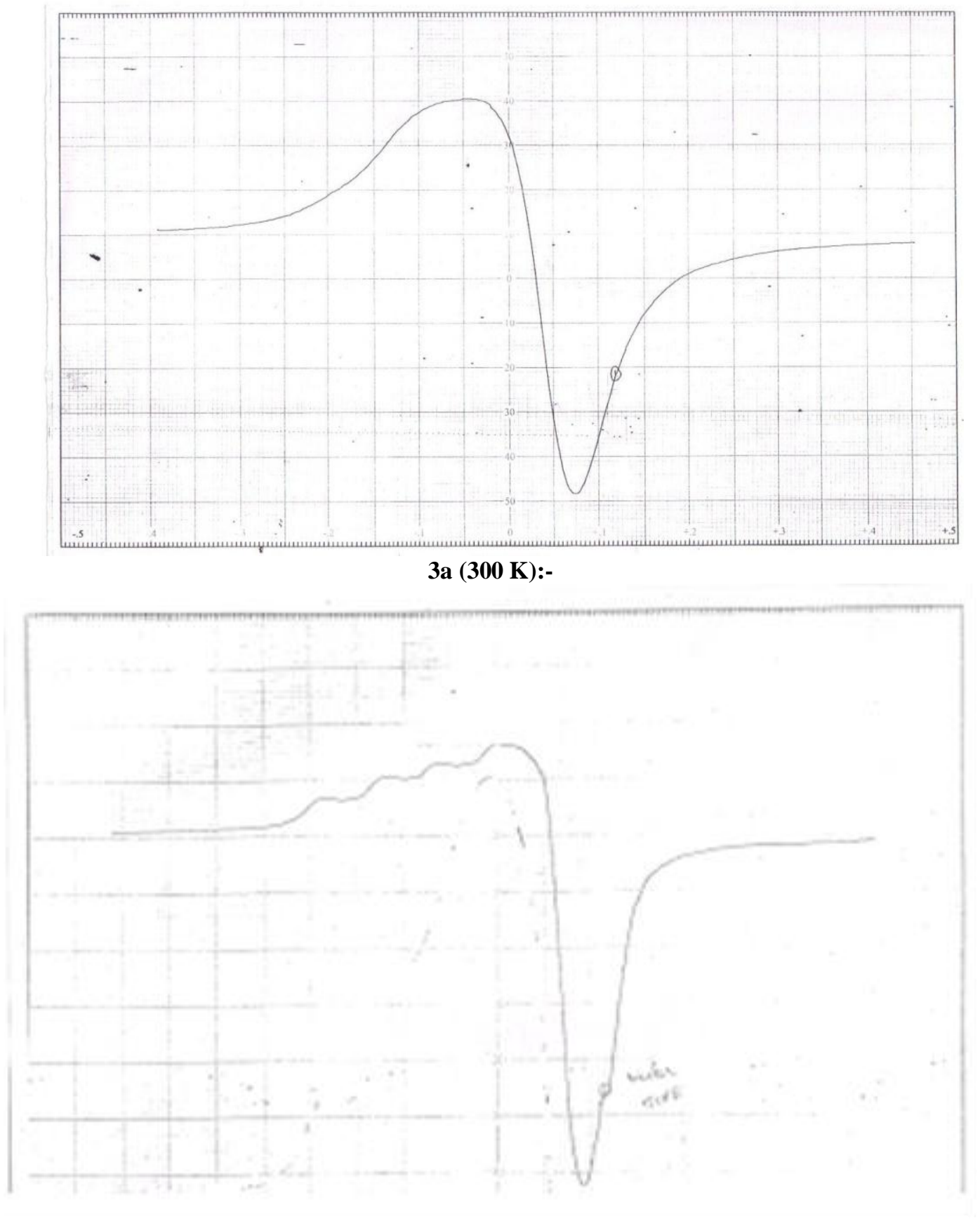

$3 b(77 \mathrm{~K}):-$

Fig. 3a b:- ESR spectrum of copper complex at $300 \mathrm{~K}$ (3a) \& $77 \mathrm{~K}$ (3b). 


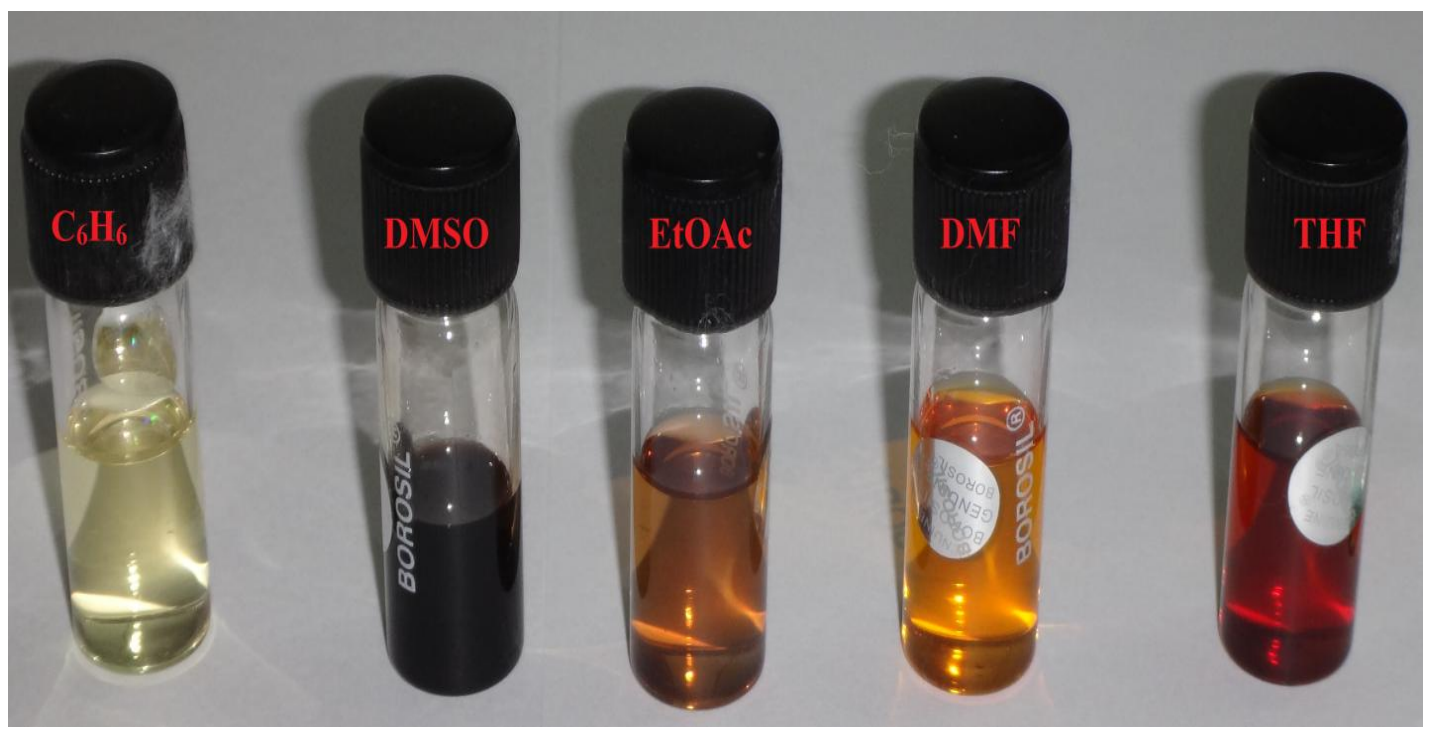

(4a):-

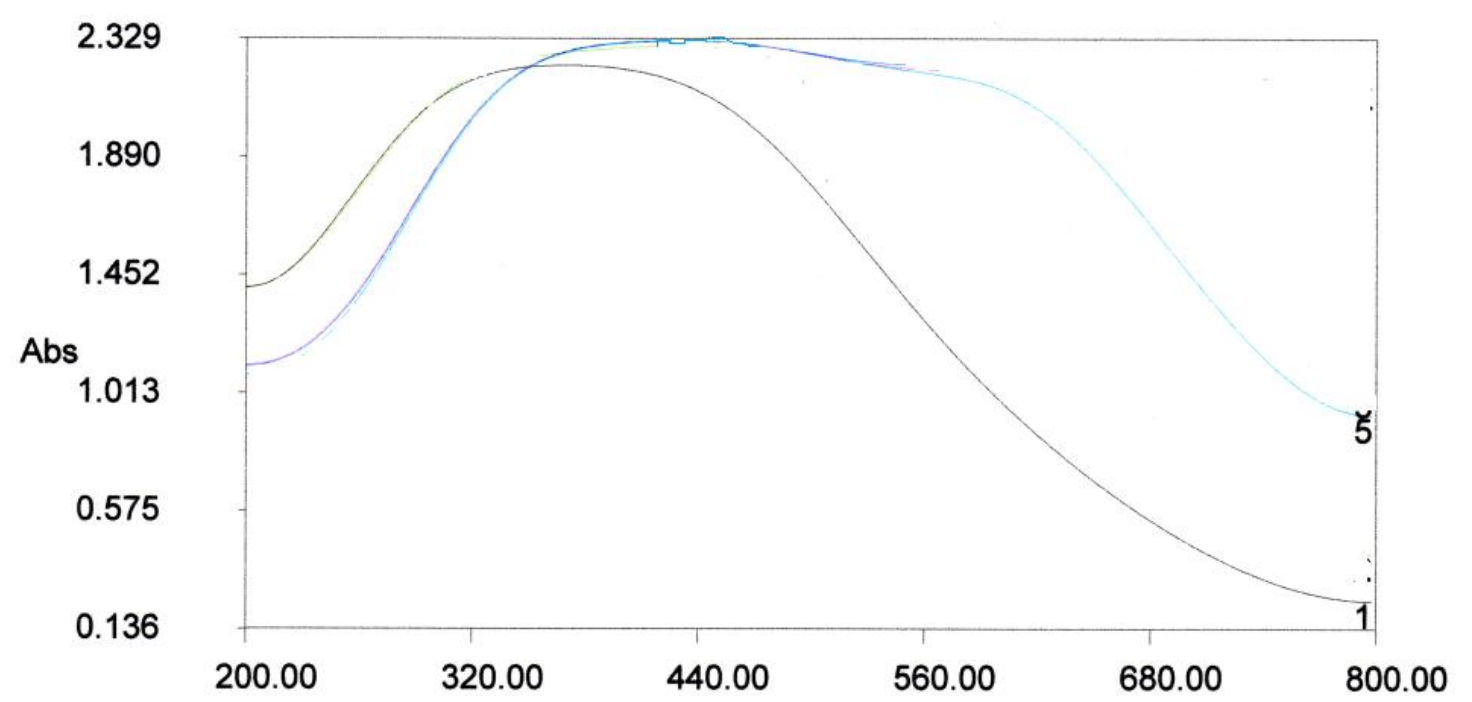

(4b):-

Fig. 4a b:- Visible spectral changes of complexes in selected solvents (4a) After irradiation of copper complex in hexane solvent using by UV transilluminator (4b) 

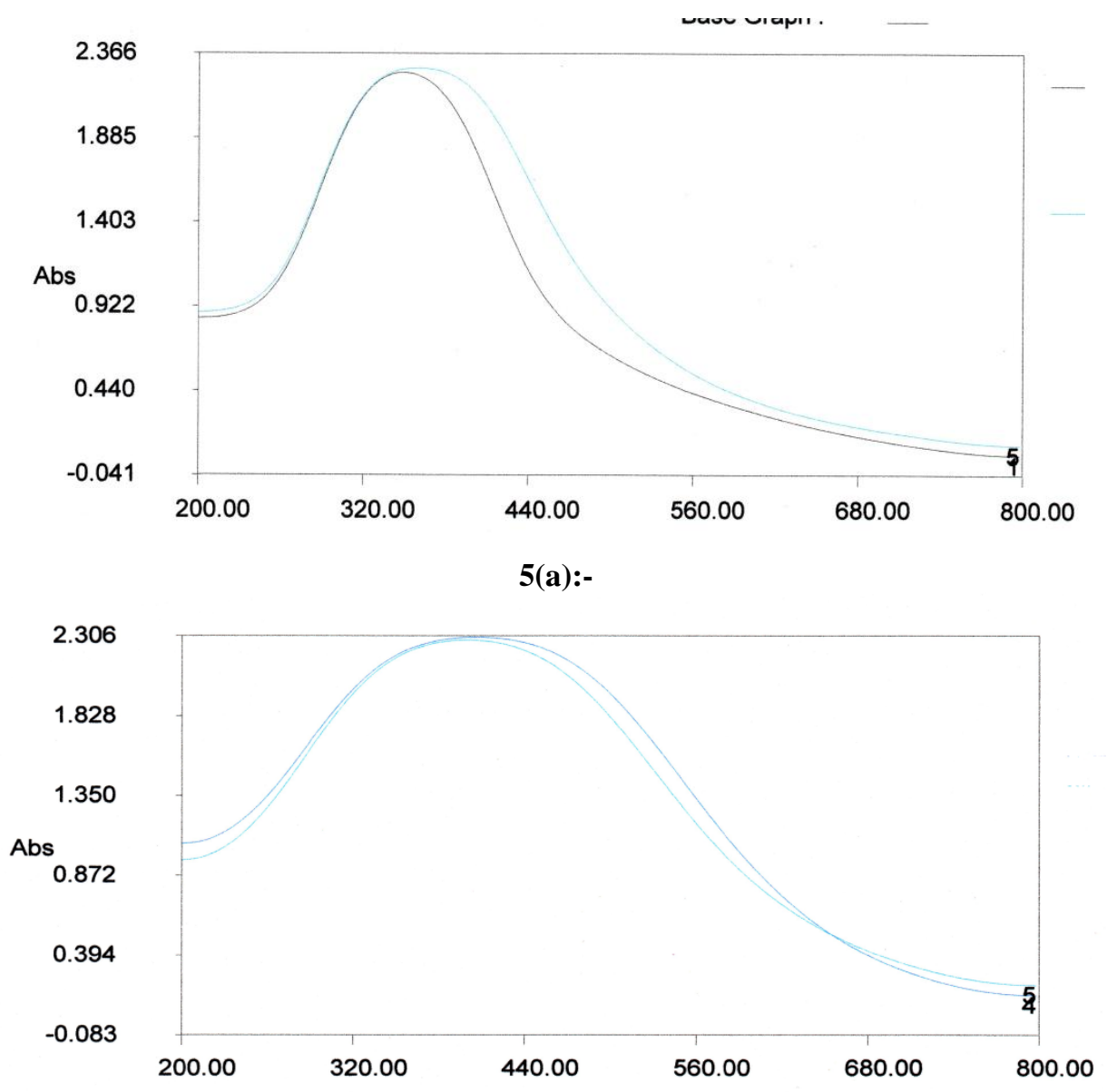

5(b):-

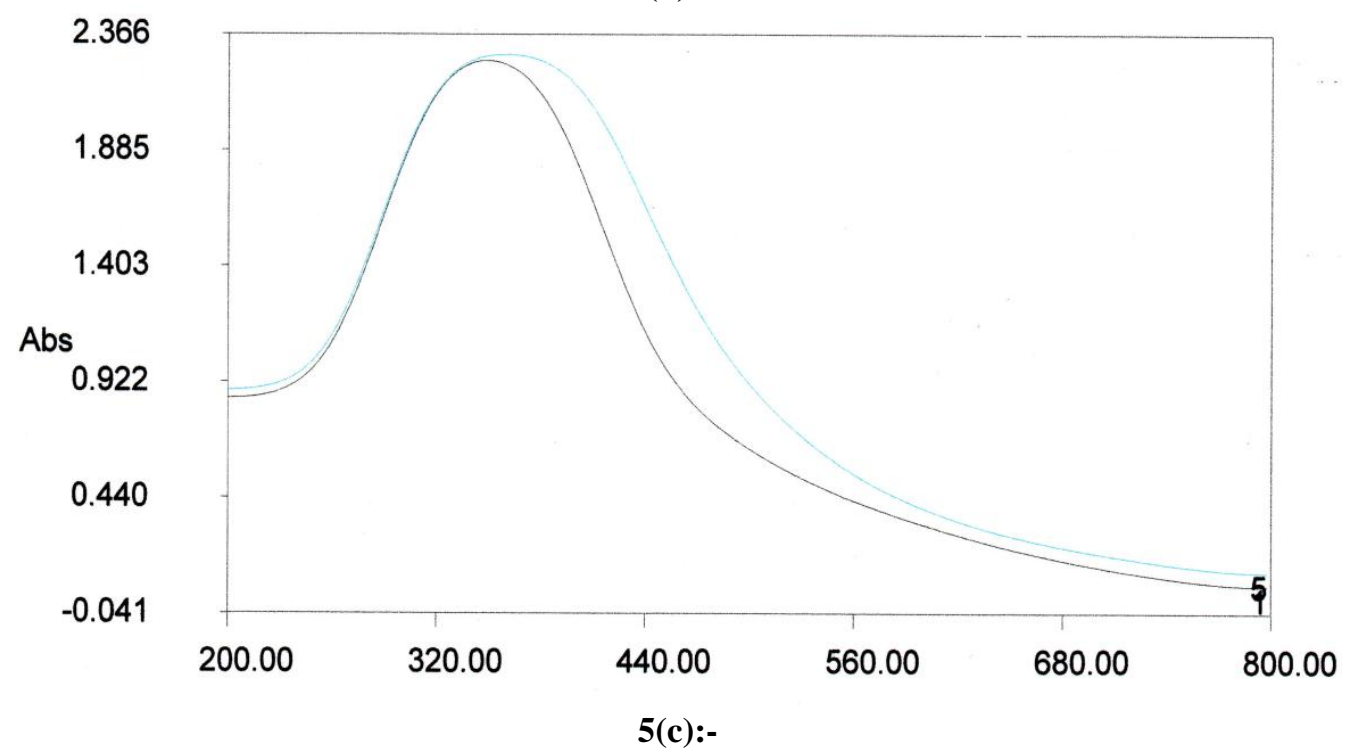



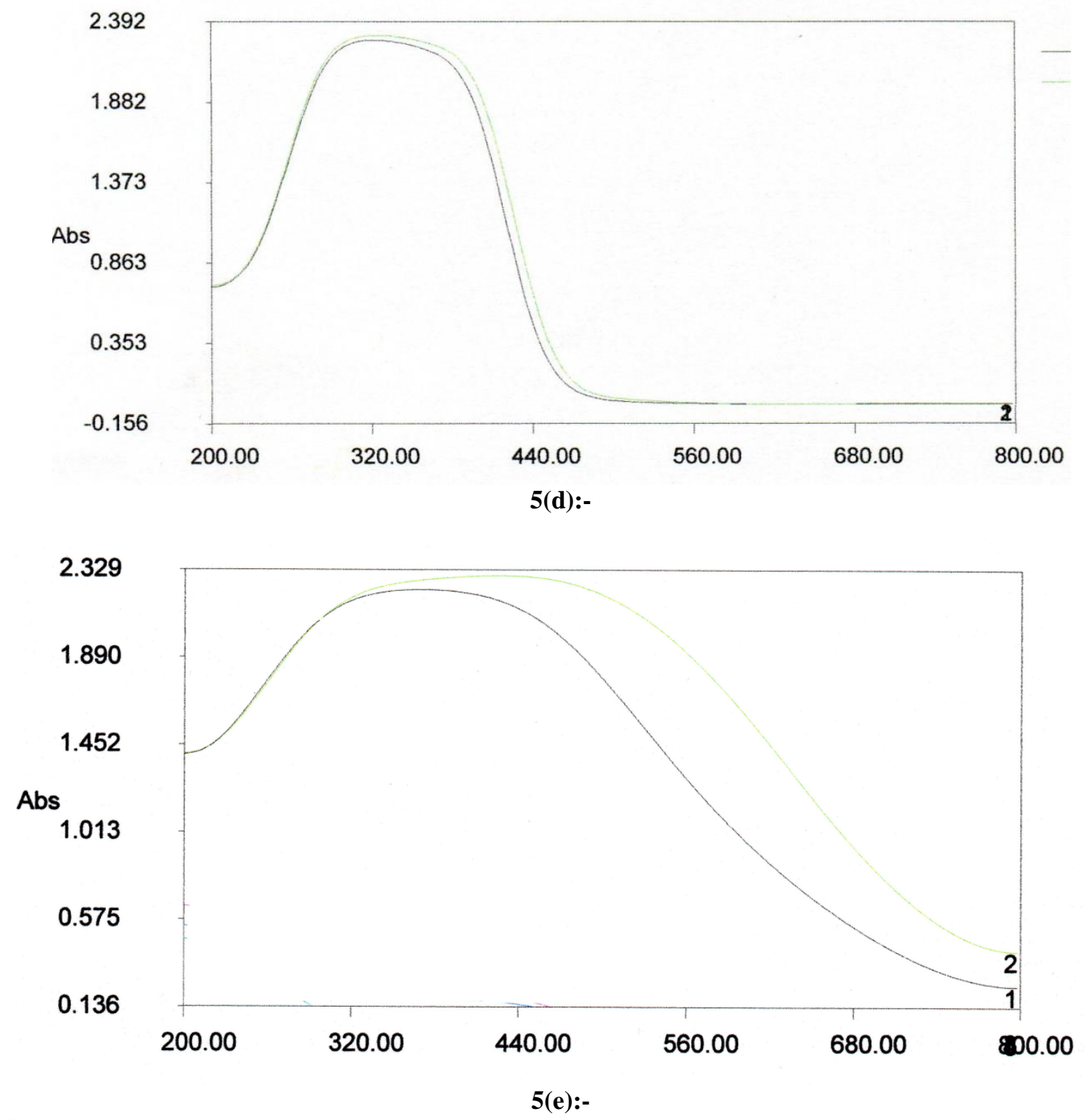

Fig 5:- The absorption spectra of complexes in the absence and presence of CT-DNA of complexes (5a-Cu(II), 5b$\mathrm{Ni}(\mathrm{II}), 5 \mathrm{c}-\mathrm{Co}(\mathrm{II}), 5 \mathrm{~d}-\mathrm{Zn}(\mathrm{II}), 5 \mathrm{e}-\mathrm{Fe}(\mathrm{III})$ Complexes). 


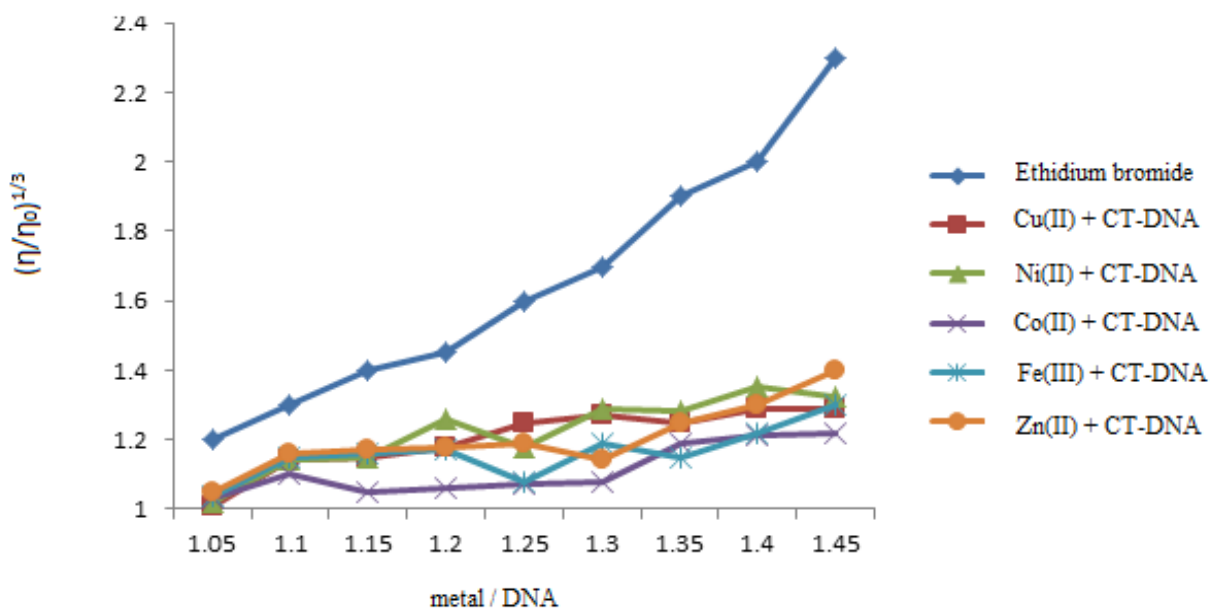

Fig. 6:- Effect on relative viscosity of CT-DNA under the influence of increasing amount mixed ligand complexes at $25 \pm 0.1^{\circ} \mathrm{C}$.

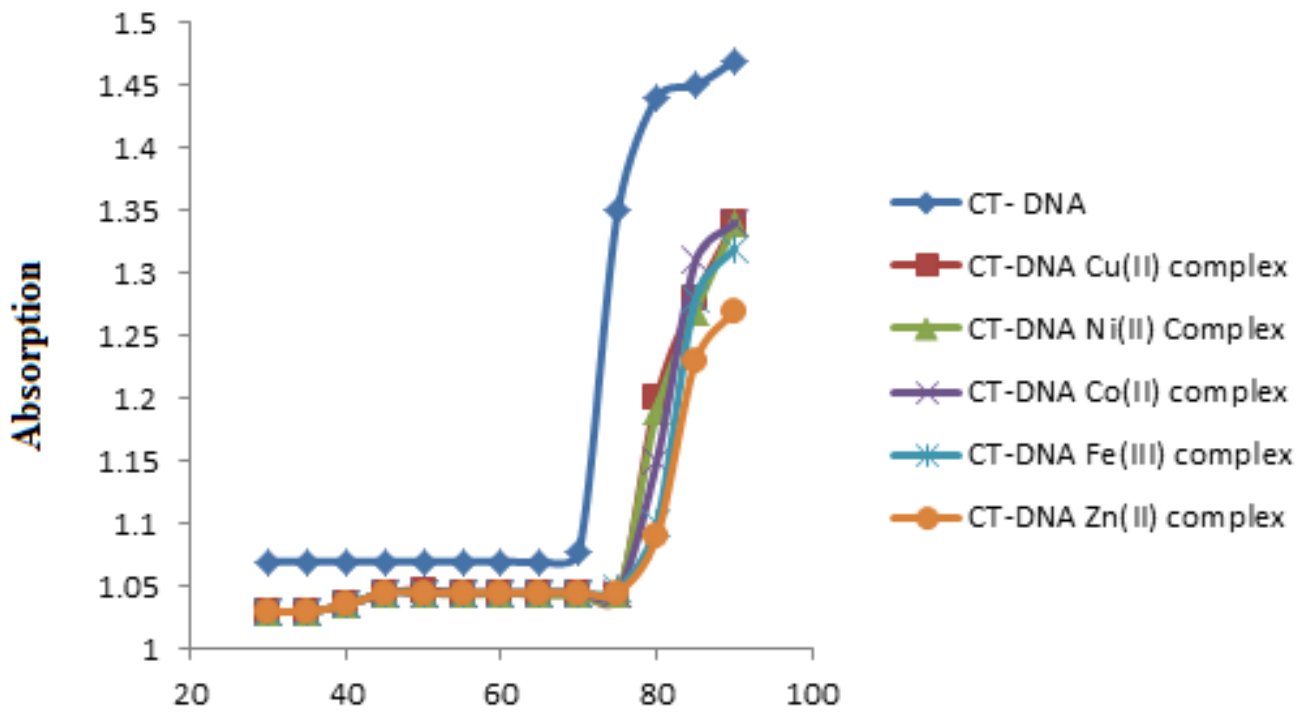

Temperature ${ }^{\circ} \mathrm{C}$

Fig. 7:- Melting curves of CT-DNA in the absence and presence of complexes. 


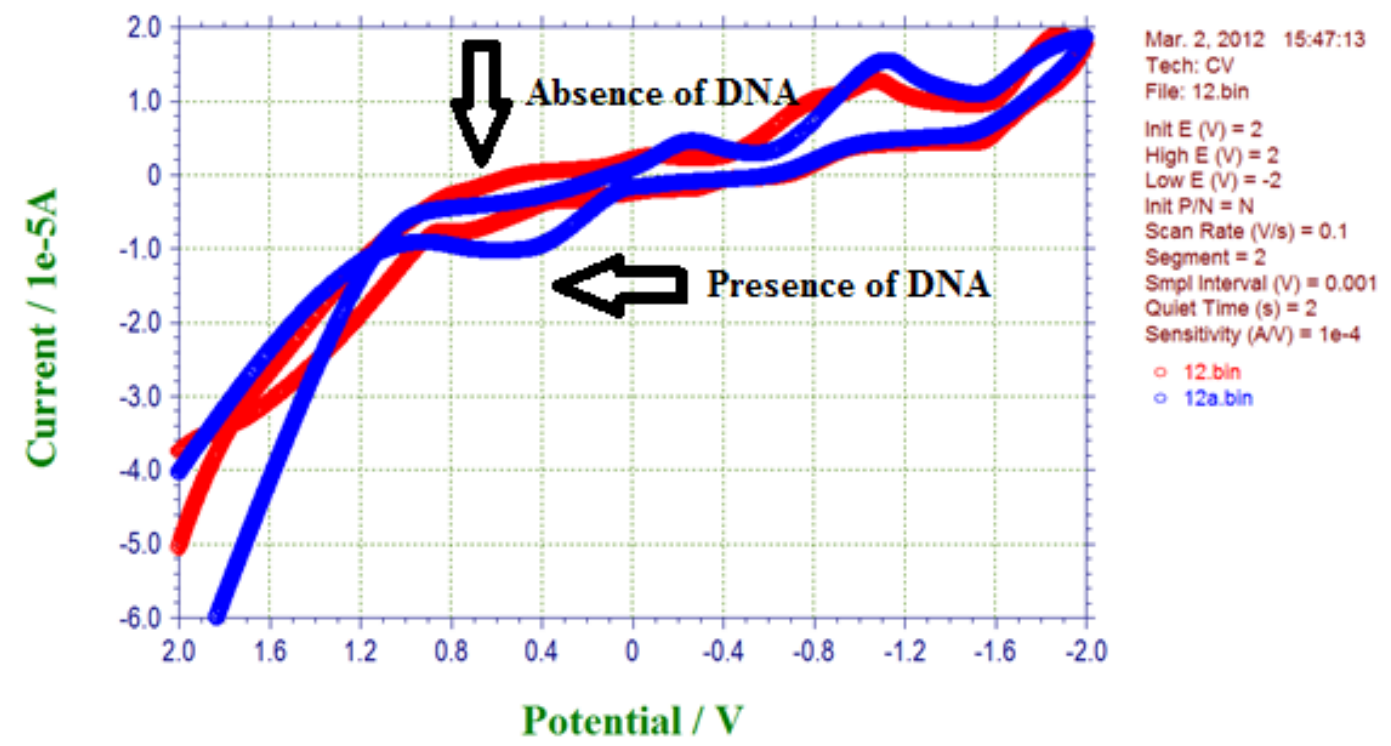

Fig 8:- The cyclic voltammograms of copper complexes in the absence and in presence of DNA at various concentration.

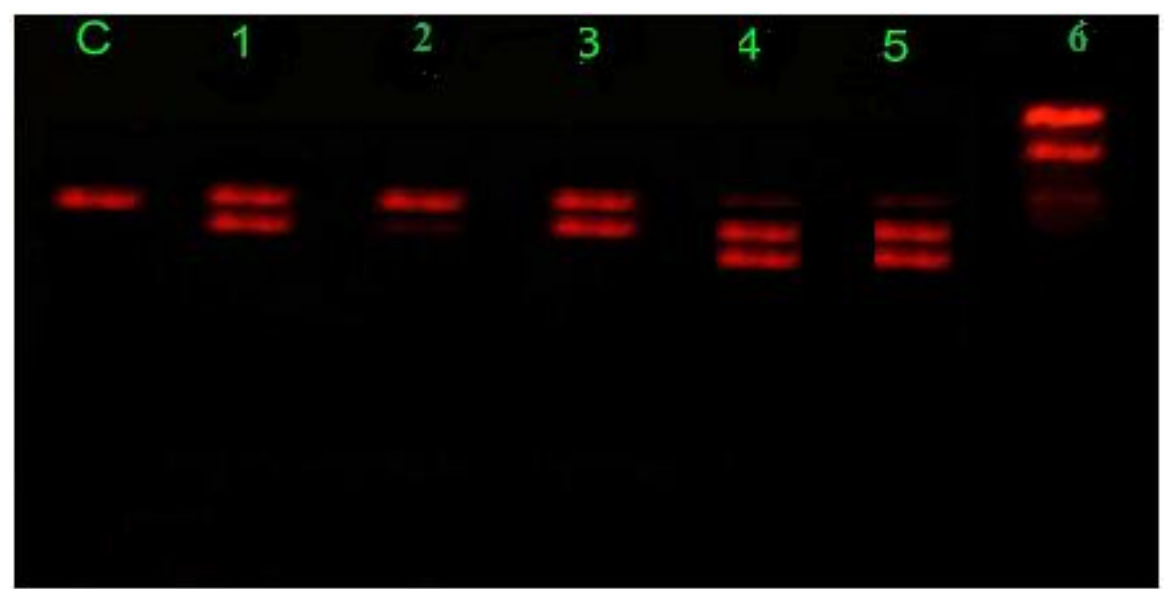

Fig 9:- Agarose gel electrophoresis of metal complexes (Lane 1: DNA $+\mathrm{H}_{2} \mathrm{O}_{2}+$ Ligand; Lane 2: DNA $+\mathrm{H}_{2} \mathrm{O}_{2}+$ Fe (III) complex; Lane 3: DNA $+\mathrm{H}_{2} \mathrm{O}_{2}+\mathrm{Co}$ (II) complex ; Lane 4: DNA $+\mathrm{H}_{2} \mathrm{O}_{2}+\mathrm{Ni}$ (II) complex; Lane 5: DNA + $\mathrm{H}_{2} \mathrm{O}_{2}+\mathrm{Cu}(\mathrm{II})$ complex; Lane 6: DNA $+\mathrm{H}_{2} \mathrm{O}_{2}+\mathrm{Zn}(\mathrm{II})$ complex) 


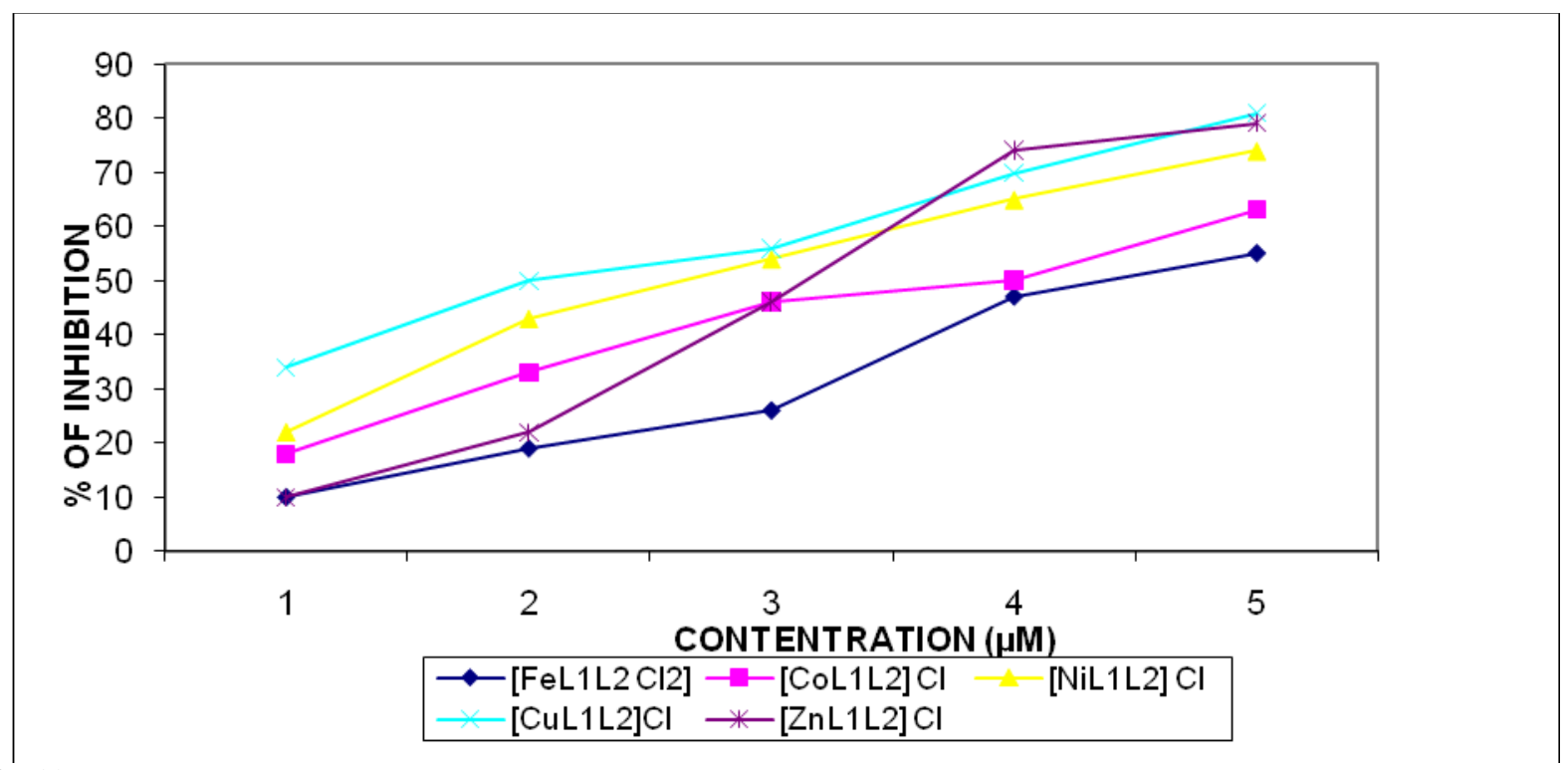

Fig 10:- Plot of percentage of inhibiting NBT reduction with an increase in the concentration of complexes.

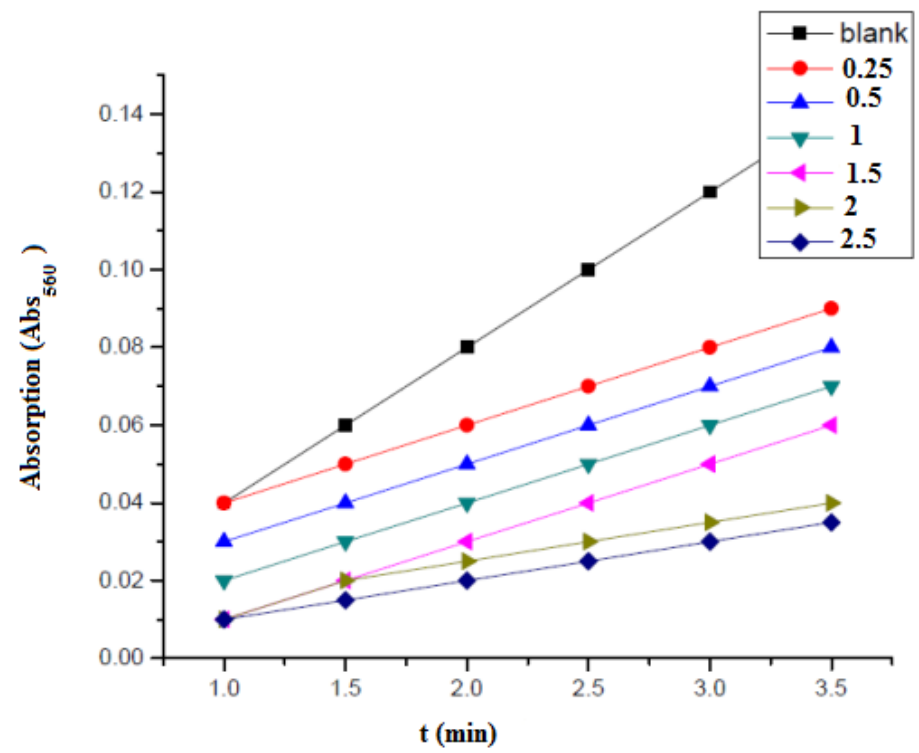

Fig 11:- Plot of absorbance values $\left(\mathrm{Abs}_{560}\right)$ against time $(\mathrm{t})$ in varies concentration of copper complex

Table 1:- Physical and analytical data of the synthesized complexes

\begin{tabular}{|c|c|c|c|c|c|c|c|c|}
\hline \multirow[t]{2}{*}{ Compound } & \multirow[t]{2}{*}{ Colour } & \multirow{2}{*}{$\begin{array}{l}\text { Yield } \\
\%\end{array}$} & \multicolumn{4}{|c|}{ Elemental analysis Found (calcd) $(\%)$} & \multirow{2}{*}{$\begin{array}{l}\text { Molar } \\
\text { conductance } \\
\left(\Omega^{-1} \mathrm{~cm}^{2} \mathrm{~mol}^{-1}\right)\end{array}$} & \multirow{2}{*}{$\begin{array}{l}\mu_{\text {eff }} \\
\text { (BM) }\end{array}$} \\
\hline & & & C & $\mathbf{H}$ & $\mathbf{N}$ & M & & \\
\hline $\mathbf{L}^{1}$ & Yellow & $85 \%$ & $\begin{array}{l}68.30 \\
(68.31)\end{array}$ & $\begin{array}{l}5.35 \\
(5.37)\end{array}$ & $\begin{array}{l}14.91 \\
(14.94)\end{array}$ & - & - & - \\
\hline $\mathbf{H L}^{2}$ & Yellow & $81 \%$ & $\begin{array}{l}69.10 \\
(69.12)\end{array}$ & $\begin{array}{l}5.36 \\
(5.39)\end{array}$ & $\begin{array}{l}5.75 \\
(5.76)\end{array}$ & - & - & - \\
\hline$\left[\mathrm{FeL}^{1} \mathbf{L}^{2} \mathrm{Cl}_{2}\right]$ & Brown & $80 \%$ & $\begin{array}{l}56.47 \\
(56.49)\end{array}$ & $\begin{array}{l}4.90 \\
(4.89)\end{array}$ & $\begin{array}{l}8.24 \\
(8.23)\end{array}$ & $\begin{array}{l}8.20 \\
(8.21)\end{array}$ & 9 & 5.92 \\
\hline$\left[\mathrm{CoL}^{1} \mathrm{~L}^{2}\right] \mathrm{Cl}$ & Brown & $82 \%$ & $\begin{array}{l}58.84 \\
(58.82)\end{array}$ & $\begin{array}{l}4.76 \\
(4.78)\end{array}$ & $\begin{array}{l}8.81 \\
(8.85)\end{array}$ & $\begin{array}{l}9.30 \\
(9.31)\end{array}$ & 35 & 3.91 \\
\hline$\left[\mathrm{NiL}^{1} \mathbf{L}^{2}\right] \mathbf{C l}$ & Dark Green & $78 \%$ & 58.81 & 4.80 & 4.82 & 9.29 & 51 & Dia \\
\hline
\end{tabular}




\begin{tabular}{|l|l|l|l|l|l|l|l|l|}
\hline & & & $(58.84)$ & $(4.78)$ & $(8.85)$ & $(9.28)$ & & \\
\hline$\left[\mathbf{C u L}^{1} \mathbf{L}^{2}\right] \mathbf{C l}$ & Green & $82 \%$ & 58.38 & 4.75 & 8.75 & 9.99 & 42 & \\
& & & $(58.40)$ & $(4.74)$ & $(8.79)$ & $(9.97)$ & & 1.83 \\
\hline $\left.\mathbf{Z n L}^{1} \mathbf{L}^{2}\right] \mathbf{C l}$ & Dark & $84 \%$ & 58.20 & 4.71 & 8.75 & 10.21 & 36 & \\
& Yellow & & $(58.23)$ & $(4.73)$ & $(8.76)$ & $(10.23)$ & & Dia \\
\hline
\end{tabular}

Table 2:- IR spectral data $\left(\mathrm{cm}^{-1}\right)$ for the free ligands and their metal complexes

\begin{tabular}{|c|c|c|c|c|c|}
\hline Compound & $\begin{array}{l}v_{\mathrm{C}=0} \\
\left(\mathbf{C m}^{-1}\right)\end{array}$ & $\begin{array}{l}v_{\mathrm{C}=\mathrm{N}} \\
\left(\mathrm{Cm}^{-1}\right)\end{array}$ & $\begin{array}{l}v_{\mathrm{M}-\mathrm{O}} \\
\left(\mathbf{C m}^{-1}\right)\end{array}$ & $\begin{array}{l}\mathbf{v}_{\mathrm{M}-\mathrm{N}} \\
\left(\mathbf{C m}^{-1}\right)\end{array}$ & $\begin{array}{l}v_{\mathrm{M}-\mathrm{Cl}} \\
\left(\mathbf{C m}^{-1}\right)\end{array}$ \\
\hline $\mathbf{L}^{1}$ & 1717 & 1616 & - & - & - \\
\hline $\mathbf{H L}^{2}$ & - & 1622 & - & - & - \\
\hline$\left[\mathrm{FeL}^{1} \mathbf{L}^{2} \mathrm{Cl}_{2}\right]$ & 1683 & $\begin{array}{l}1576 \\
1582\end{array}$ & 545 & 431 & 345 \\
\hline$\left[\mathbf{C o L}^{1} \mathbf{L}^{2}\right] \mathbf{C l}$ & 1691 & $\begin{array}{l}1581 \\
1584\end{array}$ & 537 & 436 & - \\
\hline$\left[\mathrm{NiL}^{1} \mathbf{L}^{2}\right] \mathrm{Cl}$ & 1693 & $\begin{array}{l}1591 \\
1587\end{array}$ & 521 & 425 & - \\
\hline$\left[\mathrm{CuL}^{1}{ }^{2} \mathbf{L}^{2}\right] \mathrm{Cl}$ & 1687 & $\begin{array}{l}1593 \\
1582\end{array}$ & 528 & 437 & - \\
\hline$\left[\mathbf{Z n L}^{1} \mathbf{L}^{2}\right] \mathbf{C l}$ & 1685 & $\begin{array}{l}1583 \\
1586\end{array}$ & 540 & 443 & - \\
\hline
\end{tabular}

Table 3:- Electronic absorption spectral data of the complexes in DMSO solution

\begin{tabular}{|c|c|c|c|c|}
\hline Compound & Solvent & Absorption (nm) & Band assignment & Geometry \\
\hline $\mathbf{L}^{1}$ & DMSO & 265 & $\pi-\pi^{*}$ & - \\
\hline $\mathbf{H L}^{2}$ & DMSO & 341 & $\mathrm{n}-\pi^{*}$ & - \\
\hline$\left[\mathrm{FeL}^{\mathrm{I}} \mathbf{L}^{2} \mathrm{Cl}_{2}\right]$ & DMSO & $\begin{array}{l}354 \\
792\end{array}$ & $\begin{array}{l}\mathrm{n}-\pi^{*} \\
{ }^{6} \mathrm{~A}_{1 \mathrm{~g}} \rightarrow{ }^{4} \mathrm{~T}_{1 \mathrm{~g}}\end{array}$ & Octahedral \\
\hline$\left[\mathrm{CoL}^{1} \mathbf{L}^{2}\right] \mathrm{Cl}$ & DMSO & $\begin{array}{l}351 \\
538\end{array}$ & $\begin{array}{l}\mathrm{n}-\pi^{*} \\
{ }^{1} \mathrm{~A}_{1 \mathrm{~g}} \rightarrow{ }^{1} \mathrm{~B}_{\mathrm{g}}\end{array}$ & Square planar \\
\hline$\left[\mathrm{NiL}^{1} \mathbf{L}^{2}\right] \mathrm{Cl}$ & DMSO & $\begin{array}{l}348 \\
576 \\
\end{array}$ & $\begin{array}{l}\mathrm{n}-\pi^{*} \\
{ }^{1} \mathrm{~A}_{1 \mathrm{~g}} \rightarrow{ }^{1} \mathrm{~B}_{1 \mathrm{~g}}\end{array}$ & Square planar \\
\hline$\left[\mathrm{CuL}^{1} \mathbf{L}^{2}\right] \mathrm{Cl}$ & DMSO & $\begin{array}{l}254 \\
552 \\
\end{array}$ & $\begin{array}{l}n-\pi^{*} \\
{ }^{2} B_{1 g} \rightarrow{ }^{2} A_{1 g}\end{array}$ & Square planar \\
\hline$\left[\mathbf{Z n L}^{1} \mathbf{L}^{2}\right] \mathbf{C l}$ & DMSO & 451 & $\mathrm{~L} \rightarrow \mathrm{M}$ & Square planar \\
\hline
\end{tabular}

Table 4:- ESR spectral data of the copper complex.

\begin{tabular}{|l|l|l|l|l|l|l|l|l|l|l|l|}
\hline Complex & $\mathbf{g}_{\|}$ & $\mathbf{g}_{\perp}$ & $\mathbf{g}_{\text {iso }}$ & $\mathbf{A}_{\|}$ & $\mathbf{A}_{\perp}$ & $\mathbf{K}_{\|}$ & $\mathbf{K}_{\perp}$ & $\boldsymbol{\alpha}^{2}$ & $\boldsymbol{\beta}^{2}$ & $\boldsymbol{\gamma}^{2}$ & $\mathbf{f}=\left(\mathbf{g}_{\|} / \mathbf{A}_{\|}\right)$ \\
\hline $\begin{array}{l}{\left[\mathbf{C u L} \mathbf{L}^{1} \mathbf{L}^{2}\right] \mathbf{C l}} \\
\text { at 300K }\end{array}$ & - & - & 2.12 & - & - & - & - & - & - & - & - \\
\hline $\begin{array}{l}{\left[\mathbf{C u L} \mathbf{L}^{1} \mathbf{L}^{2}\right] \mathbf{C l}} \\
\text { at 77K }\end{array}$ & 2.24 & 2.05 & - & 154 & 36 & 0.98 & 0.61 & 0.75 & 1.3 & 0.81 & 145 \\
\hline
\end{tabular}

Table 5:- Electronic absorption spectral data of copper complex in various solvents.

\begin{tabular}{|c|c|c|c|}
\hline \multirow[t]{2}{*}{ S.No } & \multirow[t]{2}{*}{ Solvent } & \multicolumn{2}{|c|}{ Wavelength, $\mathrm{nm}\left(\lambda_{\max }\right)$} \\
\hline & & before & after \\
\hline 1 & DMF & 4453 & 580 \\
\hline 2 & DMSO & 552 & 645 \\
\hline 3 & $\mathbf{C}_{6} \mathbf{H}_{6}$ & 521 & 695 \\
\hline 4 & EtOAc & 467 & 525 \\
\hline 5 & Hexane & 438 & 534 \\
\hline 6 & $\mathrm{CH}_{3} \mathrm{OH}$ & 423 & 625 \\
\hline
\end{tabular}




\begin{tabular}{|l|l|l|l|}
\hline 7 & $\mathrm{CH}_{3} \mathrm{C} \quad \mathrm{N}$ & $\mathbf{5 4 5}$ & $\mathbf{6 8 5}$ \\
\hline 8 & DCM & $\mathbf{5 1 9}$ & $\mathbf{6 1 8}$ \\
\hline 9 & THF & $\mathbf{4 2 8}$ & $\mathbf{5 1 5}$ \\
\hline
\end{tabular}

Table 6:- Electrochemical parameters for the mixed ligand complexes on interaction with CT DNA.

\begin{tabular}{|c|c|c|c|c|c|c|}
\hline \multirow[t]{2}{*}{ Compound } & \multirow[t]{2}{*}{ Redox couple } & \multicolumn{2}{|l|}{$E_{1 / 2}(V)$} & \multicolumn{2}{|c|}{$\Delta \operatorname{Ep}(\mathbf{V})$} & \multirow[t]{2}{*}{ Ipa/Ipc } \\
\hline & & Free & Bound & Free & Bound & \\
\hline$\left[\mathrm{FeL}^{1} \mathbf{L}^{2} \mathbf{C l}_{2}\right]$ & $\mathrm{Fe}(\mathrm{III}) \rightarrow \mathrm{Fe}$ (II) & $\mathbf{0 . 8 1 8}$ & 0.813 & 0.439 & 0.426 & 1.31 \\
\hline$\left[\mathrm{CoL}^{1} \mathbf{L}^{2}\right] \mathrm{Cl}$ & $\mathrm{Co}(\mathrm{III}) \rightarrow \mathrm{Co}(\mathrm{II})$ & 0.745 & 0.736 & 0.321 & 0.311 & 1.12 \\
\hline$\left[\mathrm{NiL}^{1} \mathbf{L}^{2}\right] \mathrm{Cl}$ & $\mathbf{N i}(\mathrm{II}) \rightarrow \mathrm{Ni}(\mathrm{I})$ & 0.726 & 0.711 & 0.213 & 0.208 & 1.21 \\
\hline$\left[\mathrm{CuL}^{1} \mathbf{L}^{2}\right] \mathbf{C l}$ & $\mathrm{Cu}(\mathrm{III}) \rightarrow \mathrm{Cu}(\mathrm{I})$ & -0.755 & -0.750 & -0.291 & -0.289 & 1.28 \\
\hline$\left[\mathrm{ZnL}^{1} \mathbf{L}^{2}\right] \mathbf{C l}$ & $\mathrm{Zn}(\mathrm{II}) \rightarrow \mathrm{Zn}(\mathbf{0})$ & 0.847 & 0.823 & 0.428 & 0.410 & 1.24 \\
\hline
\end{tabular}

Table 7:- Minimum inhibitory concentration of the synthesized compounds against growth of bacteria $(\mu \mathrm{g} / \mathrm{ml})$

\begin{tabular}{|l|l|l|l|l|l|}
\hline Compound & $\boldsymbol{E}$. coli & K. pneumonia & S. typhi & P.aeruginosa & S. aureus \\
\hline $\mathbf{L}^{\mathbf{1}}$ & 60 & 64 & 66 & 66 & 72 \\
\hline $\mathbf{H L}^{\mathbf{2}}$ & 52 & 67 & 53 & 58 & 63 \\
\hline$\left[\mathbf{F e L}^{\mathbf{1}} \mathbf{L}^{\mathbf{2}} \mathbf{C l}_{\mathbf{2}}\right]$ & 31 & 32 & 37 & 23 & 22 \\
\hline$\left[\mathbf{C o L}^{\mathbf{1}} \mathbf{L}^{\mathbf{2}}\right] \mathbf{C l}$ & 32 & 30 & 31 & 29 & 23 \\
\hline$\left[\mathbf{N i L}^{\mathbf{1}} \mathbf{L}^{\mathbf{}}\right] \mathbf{C l}$ & 38 & 25 & 36 & 32 & 28 \\
\hline$\left[\mathbf{C u L}^{\mathbf{1}} \mathbf{L}^{\mathbf{2}}\right] \mathbf{C l}$ & 34 & 26 & 38 & 34 & 26 \\
\hline$\left[\mathbf{Z n L}^{\mathbf{1}} \mathbf{L}^{\mathbf{2}}\right] \mathbf{C l}$ & 28 & 22 & 31 & 33 & 18 \\
\hline Pencillin & 10 & 15 & 6 & 12 & 4 \\
\hline Ampicillin & 12 & 10 & 8 & 4 & 6 \\
\hline Vancomycin & 6 & 14 & 12 & 10 & 8 \\
\hline Ofloxacin & 8 & 10 & 4 & 6 & 14 \\
\hline
\end{tabular}

Table 8:- Minimum inhibitory concentration of the synthesized compounds against growth of fungi ( $\mu \mathrm{g} / \mathrm{ml})$

\begin{tabular}{|l|l|l|l|l|l|}
\hline Compound & A. niger & $\boldsymbol{R}$.stolonifer & A. flavus & R. bataicola & C. albicans \\
\hline $\mathbf{L}^{\mathbf{1}}$ & 60 & 66 & 72 & 80 & 50 \\
\hline $\mathbf{H L}^{2}$ & 52 & 65 & 53 & 63 & 56 \\
\hline$\left[\mathbf{F e L}^{1} \mathbf{L}^{2} \mathbf{C l}_{\mathbf{2}}\right]$ & 15 & 21 & 32 & 28 & 20 \\
\hline$\left[\mathbf{C o L}^{1} \mathbf{L}^{2}\right] \mathbf{C l}$ & 14 & 25 & 36 & 22 & 19 \\
\hline$\left[\mathbf{N i L}^{1} \mathbf{L}^{2}\right] \mathbf{C l}$ & 26 & 28 & 39 & 20 & 22 \\
\hline$\left[\mathbf{C u L}^{1} \mathbf{L}^{2}\right] \mathbf{C l}$ & 27 & 31 & 38 & 32 & 35 \\
\hline$\left[\mathbf{Z n L}^{1} \mathbf{L}^{2}\right] \mathbf{C l}$ & 18 & 15 & 24 & 31 & 23 \\
\hline Nystatin & 12 & 15 & 5 & 15 & 16 \\
\hline Kctoconazole & 14 & 9 & 15 & 8 & 15 \\
\hline Clotrimazole & 10 & 6 & 17 & 14 & 8 \\
\hline
\end{tabular}

\section{Antimicrobial Activity:-}

The in vitro biological screening effects of the investigated compounds were tested against the bacterial species such as S. aureus, E. coli, K. pneumoniae, P. vulgaris and P. aeruginosa and fungal species includes A. niger, R. stolonifer, A. flavus, $R$. bataicola and $C$. albicans by the disc diffusion method. The minimum inhibitory concentration (MIC) values of the synthesised compounds were summarized in Tables 7 and 8 . A comparative study of the ligands and their complexes (MIC values) indicates that complexes exhibit higher antimicrobial activity than the free ligands. The enhanced activity of the complexes can be explained on the basis of Overtone's concept (Belaida et al., 2008) and Tweedy's Chelation theory (Dharamaraj et al., 2001). According to Overtone's concept of cell permeability, the lipid membrane that surrounds the cell favors the passage of only the lipid soluble materials makes which liposolubility as an important factor, which controls the antimicrobial activity. On chelation, the polarity of the metal ion will be reduced to a greater extent due to the overlap of the ligand orbital and partial sharing of the positive charge of the metal ion with donor groups. Further, it increases the delocalization of $\Pi-$ electrons over the whole chelate ring and enhances the lipophilicity of the complexes. 
Metal chelates bear polar and nonpolar properties together; this makes them suitable for permeation to the cells and tissues. In addition, chelation may enhance or suppress the biochemical potential of bioactive organic species. Changing hydrophilicity and lipophilicity probably leads to bring down the solubility and permeability barriers of cell. Further, lipophilicity, which controls the rate of entry of molecules into the cell, is modified by coordination, so the metal complex can become more active than the free ligand (Farrell, 2007). However, compared to the antimicrobial activity of the standards, the activity exhibited by the ligand and the metal complexes was lower.

This increased lipophilicity enhances the permeation of the complexes into lipid membranes and blocking of the metal binding sites in the enzymes of microorganisms. These complexes also disturb the respiration process of the cell and thus block the synthesis of the proteins that restricts further growth of the organism and as a result microorganisms die. The increased activity of the complexes may also be explained on the basis of their high solubility, fitness of the particles, size of the metal ion and the presence of the bulkier organic moieties. The different lipophilic behaviour of the aromatic residues such as antipyrine, and furfuraldehyde is involved in the biological activity mechanisms. The rise in the antimicrobial activity of the mixed ligand complexes may be owing to the effect of the metal ion on the normal cell processes (Raman et al., 2012). The activity order of the synthesized compounds is as follows:

$\mathrm{Cu}(\mathrm{II})>\mathrm{Ni}(\mathrm{II})>\mathrm{Co}(\mathrm{II})>\mathrm{Fe}(\mathrm{III})>\mathrm{Zn}(\mathrm{II})>\mathrm{L}$

\section{Conclusion:-}

Novel mixed ligand complexes with 4-aminoantipyrine were synthesized and characterized by elemental analysis, spectral (FT-IR, UV-Vis, ${ }^{1} \mathrm{H}-\mathrm{NMR}$ and ESR). From the DNA binding studies indicates that the complexes have intercalative binding mode. The results of agarose gel electrophoresis indicate that the complexes exhibit cleavage capability of pUC19 DNA in the presence of $\mathrm{H}_{2} \mathrm{O}_{2}$. The present system stabilized unusual oxidation state of $\mathrm{Fe}(\mathrm{III})$ complex during electrochemical conversion. Antimicrobial activity studies show that the complexes showed better biological activity as compared to free ligand.

\section{References:-}

1. Abd El Rehim, S.S., Ibrahim, M.A.M., Khalid, K.F., 2001.Mater. Chem. Phys. 70, 268-273.

2. Akdi, K., Vilaplana, R.A., Kamah, S., Gonzalez-Vilchez, F., 2005. J. Inorg. Biochem. 99, 1360-1368.

3. Babu, M.S.S., Reddy, K.H., Pitchika, G.K., 2007. Polyhedron. 26, 572-580.

4. Belaida, S., Landreaub, A., Djebbara, S., Benali-Baiticha, O., Bouetb, G., Philippe Boucharac, J.,2008. J. Inorg. Biochem. 102, 63-69.

5. Bhirud, R.G., Shrivastava, T.S., 1991. Inorg. Chim. Acta. 179, 125-131.

6. Dhar, S., Senapati, D., Das, P.K., Chattopadhyay, P., Nethaji, M., Chakravarty, A.R., 2003. J.Am. Chem. Soc. $125,12118-12124$.

7. Dharamaraj, N., Viswanathamurthi, P., Natarajan, K., 2001.Transition Met. Chem. 26, 105-109.

8. Dutt, R. L., Syamal, A., 1992. Elements of magneto chemistry, second Edn. East- West press, New Delhi, pp.203-250.

9. El-Ayaan, U., Murata, F., Fukuda, Y., 2001. Monatsh. Chem. 132, 1279-1294.

10. Farrell, N., 2007. Coord. Chem. Rev. 232, 1-31.

11. Fridovich, I., 1995. Annu. Rev. Biochem. 64, 97-112.

12. Hassan, H.M., Fridovich, I., 1981. Eur. J. Rheumatol. Inflamm. 4,160-172. Hathaway, B. J., Billing, D.E., 1970. Coord. Chem. Rev. 5, 143-207.

13. He, X.F., Chen, H., Xu, L., Ji, L.N., 1998. Polyhedron. 17, 3161-3166, Ismail, K.Z., 2005.Transition. Met. Chem. 25, 522-528.

14. Ismail, K. Z., El-Dissouky, A., Shehadab, A. Z., 1997. Polyhedron. 16, 2903-3069.

15. Ji, L.-N., Zou, X.-H. , Liu, J.-G., J. 2001. Coord. Chem. Rev. 216-217, 513-536.

16. Kelly, J.M., Tossi, A.B., McConell, D.J., OhUigin, C., 1985. Nucleic Acids Res. 13, 6017-6034.

17. Koning, P.K., Cantilena, L., 1994. Ann. Intern. Med. 154, 590-591.

18. Kumar, R.S., Sasikala, K., Arunachalam, S., J. 2008. Inorg. Biochem. 102, 234-241.

19. Lever, A.P.B., 1984. Inorganic electronic spectroscopy, second Edn., Elsevier science New York.

20. Long, E.C., Barton, J.K., 1990. Acc. Chem. Res. 23, 271-273.

21. Marcus, Y., 1993. Chem. Soc. Rev. 22, 409-416.

22. McCoubery, A., Latham, H.C., Cook, P.R., Rodger, A., Lowe G., 1996. FEBS Lett. 73, 380-387.

23. Miller, A.-F., Sorkin, D.L., 1997. Comments Mol. Cell. Biophys. 9, 1-48. 
24. Miller A.-F., in: L.J. Que, W. Tolman (Eds.), 2003. Coordination Chemistry in the Biosphere and Geosphere, Comprehensive Coordination Chemistry II, Vol. 8, Elsevier Ltd., pp. 479-506.

25. Mitrunen, K., Sillanpaa, P., Kataja, V., Eskelinen, M., Kosma, V., Benhamou, S., Uusitupa, M., Hirvonen, A., 2001. Carcinogenesis. 22, 827- 829.

26. Neyhart, G.A., Grover, N., Smith, S.R., Kalsbeck, W.A., Fairly, T.A., Cory, M., Thorp, H.H.,1993. J. Am. Chem. Soc. 115, 4423-4428.

27. Oberly, L.W., Buettner G.R., 1979. Cancer Res. 39, 1141 -1149.

28. Oberley, L.W., 2005. Biomed. Pharmacother. 59, 143-148.

29. Pogni, R., Bartoo, M.C., Diaz, A., Basosi, R., 2000. J. Inorg. Biochem. 79, 333-337.

30. Poulsen, H.E., Loft, S., 1998. J. Heptal. 6, 374-382.

31. Pyle, A.M., Rehmann, J.P., Meshoyrer, R., Kumar, C.V., Turro, N.J., Barton, J.K., 1989. J. Am. Chem. Soc. 111, 3051-3058.

32. Raman, N., Sobha, S., Selvaganapathy, M., 2012. Int. J. Pharm. BioSci. 3, 251-268.

33. Sone, K., Fukuda, Y., 1987. Inorganic thermochromism, Inorganic Chemistry Concepts, Vol. 10, Springer, Berlin.

34. Sun, Y-X., Zhang, R., Ding, D-J., Liu, S., Wang, B- L., Wang, Y-L., Lin, Y-X., 2006. Struct. Chem. 17, 655665.

35. Tan, L-F., Chao, H., Zhou, Y-F., Ji, L-N., 2007. Polyhedron. 26, 3029-3036.

36. Tas, E., Aslanoglu, M., Kilic, A., Kara, Z., 2006. J. Coord. Chem. 59, 861-872.

37. Temel, H., Ilhan, S., Sekerci, M., Ziyadanogullari, R., 2002. Spectrosc. Lett. 35, 219-228.

38. Waring, M.J., 1965. J. Mol. Biol. 13, 269-274.

39. Wu, B.Y., Gao, L.H., Daun, Z. M., Wang, K.Z., 2005. J. Inorg. Biochem. 99, 1685-1691.

40. Yadav, P.N., Demertzis, M.A., Demertiz Shoulika, S., West, D.X., 2003. Inorg. Chim. Acta. 349, 30-36. 